\title{
An Overview of Customer Loyalty, Perceived Service Quality and Customer Satisfaction: Brief on Saudi Grocery Stores
}

\author{
Dr. Naif Mutlaq Al Otaibi \\ Othman Yeop Abdullah Graduate School of Business \\ Universiti Utara Malaysia
}

Kausar Yasmeen (Corresponding author)

Universiti Utara Malaysia

Email:eco.yasmeen@gmail.com

Doi:10.5296/ jebi.v1i1.6657 URL: http://dx.doi.org/10.5296/ jebi.v1i1.6657

\begin{abstract}
Lack perceived quality in Saudi Arabia has been repeatedly identified as one of the most formidable barriers to people for engaging in customer loyalty.Despite, the widespread establishment of shopping malls all over the country, the statistics revealed that Saudi consumers, although trying grocery shopping in some shopping malls, still prefer to do their grocery shopping activities in traditional grocery stores and convenience stores (Othaim, 2012). This paper provides an overview perceived service quality and customer satisfaction which affect Saudi customer loyalty and it reviews relevant previous studies that investigate the relationships among said three variables. This paper provides the critical remarks and direction for future research.
\end{abstract}

Keywords: Customer loyalty, perceived service quality, customer satisfaction 


\section{Introduction and Background}

The Saudi retail market has seen booming growth with a large number of shopping malls emerged as a result of foreign investment in the Saudi retail sector (GCC, 2012). The existence of new shopping malls, on the other hand, contributes to the development of grocery stores in the shopping malls. The increasing number of shopping malls in the Saudi retail sector could be due to several factors such as the dramatic increase in the country's population, improved education, changing shopping habits of Saudi consumers and the urbanization of the country's rural areas (Business Monitor International, 2012). Despite, the widespread establishment of shopping malls all over the country, the statistics revealed that Saudi consumers, although trying grocery shopping in some shopping malls, still prefer to do their grocery shopping activities in traditional grocery stores and convenience stores (Othaim, 2012). The Retail ME Report (2012) indicates that most grocery retail services at present are still served by small local or traditional grocery stores. Meanwhile, another report by Al Rajhi Capital predicts that traditional stores would represent $59 \%$ of the retail market in Saudi Arabia in 2013 (Al Rajhi Capital, 2013). This clearly indicates that Saudi grocery shoppers experience lack of loyalty to grocery shopping in the shopping malls that they have tried.

The low loyalty level of Saudi consumers toward the grocery stores in the shopping malls could be due to several reasons. One of that could be suggested from the report by Saudi Standard, Metrology and Quality Organization (2012) which revealed that the grocery stores in the Saudi shopping malls had faced issues with the quality of products and services' quality provided to the Saudi shoppers. The report added that such issues had affected the confidence of the Saudi shoppers. Saudi Arabia grocery consumers still believed that products sold in the grocery stores in the shopping malls are not fresh compared to products that traditional grocery stores sell. Saudi Arabia grocery consumers also believed that service quality provided by the grocery stores in the shopping malls is still below their expectation. Saudi grocery consumers are used to do their grocery shopping in the traditional grocery stores in their neighbourhood, and they have close and personal relation, that they developed with the owner or workers. It is a contradictory situation that they find when they do their shopping in the grocery stores in the shopping malls. These perceptions pose a great challenge to Saudi grocery stores in the shopping malls (Mousa,2012; Othaim,2012) thus they have to find the solution in order to ensure their future survival.

Changes in Saudi Arabia consumer lifestyles and demographic factors could also contribute in the changing consumption pattern, satisfaction and loyalty. The dramatic increase in population, improvement of education, increasing expectations and urbanization of the country's rural areas may play a vital role in the current Saudi Arabia consumer shopping pattern and behavior. Saudi customer's personal grooming, clothing, leisure habits, saving, investment, communication facilities, transport, travelling and tourism habits are also changed. In this context, Mc Carthy (2011) and Monroe (2003) asserted that consumers' demographic characteristics and their lifestyles do affect the choice of benefits they want and the importance of these benefits as well as their willingness to pay for them.

The importance of customer retail store loyalty in grocery retail has become significant area 
with priority in the field of marketing research (Berry, 2000; Fullerton, 2005; Harris \& Goode, 2004; Hartman \& Spiro, 2005; Reynolds \& Arnold, 2000; Srinivasan, Anderson, \& Ponnavolu, 2002; Wong \& Sohal, 2003). Berry (2000) highlighted that studying retail store loyalty is crucial mainly because of the current phenomenon where customers find it difficult to distinguish between the stores, perceived from the brands of retailers that are on offer. Apart from that, loyal customers have to be reported as they have higher retention rates and committing a higher share of their category spending to the place where they buy their products as they are more likely to recommend a place to other potential customers (Kotler et $a l ., 2010)$. This idea of customers recommending the place to their friends and family members rooted in the lifestyles of Saudi people in which people are highly influenced by what their friends and family members recommend to them (Ahmad, 2012). Astonishingly, this concept or research area has yet to receive an appropriate interest in the marketing and consumer behaviour researches (Wallace, Giese, \& Johnson, 2004).

In this context, the GRDI Report (2010) indicates that traditional grocery retailing remains dominant in Saudi Arabia, which has contributed to 51\% of sales value in 2010. This claim is also supported by Retail ME Report (2012) which indicates that most grocery retail services at present are still served by small local groceries. Another report predicts that traditional stores would represent 59\% of the retail market in Saudi Arabia in 2013 (Al Rajhi Capital, 2013). Indeed, statistical report of Saudi Ministry of Municipal and Rural Affairs 2010 revealed that the retail sector in the Saudi market is fragmented which is characterised by the dominance of sales in individual stores (ACG, 2009).

As far as the grocery retail market in Saudi Arabia is concerned, there seems to be a few problems related to quality of services provided by the grocery retail stores in Saudi shopping malls. A report by Saudi Standard, Metrology and Quality Organization (2012) revealed that the grocery retail in Saudi shopping malls had faced many issues with the products and services' quality provided to Saudi shoppers. The report added that such issues affected the confidence of Saudi shoppers about the quality of the groceries offered by these shopping malls, leading to a waning trust among the shoppers. This lack of confidence in the quality of groceries translates into a fact where many of them are avoiding big shopping malls for their grocery shopping. Many shoppers believe that groceries stored in a big shopping malls are comparably less fresh than those available in a small grocery stores because the former is assumed to be kept for a long time.

Reports on the quality of services and products provided by official sources such as Standard, Metrology and Quality Organization in the Saudi are of great use to grocery retailers in the shopping malls as it would help them to evaluate their customers' satisfaction about service quality provided. However, such reports seem to be grounded in small scale studies and direct complaints from some customers who share their dissatisfaction with their own grocery shopping experiences (small-scale perceived service quality). This is because there is a lack of actual research on the service quality perceived by customers regarding their grocery shopping experiences in Saudi Arabia.

Since most of those who do their grocery shopping at small local groceries and convenience 
stores appear to have the poor experience of buying their groceries from the leading retails of shopping malls (Mousa, 2012), this posed a real challenge for grocery retailers in ensuring customer loyalty. Despite the Saudi government's effort to introduce more systematic and organized shopping malls, Saudi consumers still prefer to shop in small and unorganized retail format and small grocery stalls (Mousa, 2012; Othaim, 2012). The Saudi government and the grocery retailers in the shopping malls are desperate to uncover factors that could contribute to Saudi consumer loyalty and satisfaction. This clue is crucial to ensure the success of the shopping malls business in Saudi Arabia. The findings from research conducted on this particular aspect provide empirical evidence necessarily that benefits the practical, holistic and strategic planning of the shopping malls industry. Thus, it is critical for grocery retailers in the Saudi shopping malls to continue evaluating the service quality provided to their customers in ensuring high customer loyalty.

Although researchers seem to agree on the link between products and services' quality and customer satisfaction which by itself constitutes an important determinant of store loyalty (Oliver, 1999; Rahim, Osman, \& Ramayah, 2010; Wallace, Giese, \& Johnson, 2004), the literature findings on the causal order of service quality and customer satisfaction, on which the two constructs is a better predictor for customer loyalty (Bolton \& Drew, 1991; Cronin \& Taylor, 1992) remain inconclusive. One group of researchers believe that customer satisfaction is antecedent to service quality (Beerli, Martin, \& Quintana, 2004; Bitner, 1990; Bolton \& Drew, 1991; Brady \& Robertson, 2001; Dabholkar, 1995; Winstanley, 1997).

Another group of researchers believe that service quality affects store loyalty through the mediating the influence of customer satisfaction (Balaji, 2009; Bedi, 2010; Kassim \& Abdullah, 2010; Kumar, Kee, \& Charles, 2010; Lee \& Hwan, 2005; Naeem \& Saif, 2009; Yee, Yeung, \& Cheng, 2010). A third perspective maintains that there is a direct relationship between service quality and store loyalty (Taylor \& Cronin, 1994). The non-conclusive findings of the said relationships show that the impact of service quality and customer satisfaction on customer loyalty is complex and it merits further investigation. Furthermore, Dabholkar (1995, cited in Brady \& Robertson, 2001) argued that the relationship is specific to the situation which means that relationships between variables might be different, depending on the industry that is being examined and culture of the people where study is conducted.

In addition, Mousa (2013) said that Saudi Arabia has experienced rapid socio-cultural changes caused by the accelerating economy, which allowed Saudis to travel to Western countries for education and tourism, exposing them to Western foods and culture. Saudi young generation's eating habits are becoming like western food and culture. Thus, Brady and Robertson (2001) recommended that researchers should examine such relationships in their future studies based on their local culture. By conducting more research in this area, scholars will be able to understand more about the relationship between consumer loyalties, service quality and consumer satisfaction.

A number of research studies reported that the determinants of service quality vary across industries, countries and cultures (Donthu \& Yoo, 1998; Imrie, Cadogan, \& McNaughton, 
2002; Veronica, 2011) and it differs from developed and developing countries (Malhotra, Ulgado, Agarwal, \& Baalbaki, 1994). Despite the changes driven by globalization, society will still retain its fundamental cultural values and identities over many generations (Hofstede, 1984; Schwartz, 1997; Wong\& Maher, 1998). Unfortunately, the findings of the studies on grocery service quality have not been validated in a cross-country setting (Devi \& Sellappan, 2009). Consequently, a contextualised Saudi research is urgently needed in order to gain a deeper and richer understanding on how customers perceive the service quality provided by the Saudi grocery retailers.

\section{Customer Loyalty}

It is identified that customer loyalty as a construct is comprised of both customer's attitude and behavior. Customers' attitudinal component represents notions like: repurchase intention or purchasing additional products or services from the same company, willingness of recommending the company to others, demonstration of such commitment to the company by exhibiting a resistance to switching to another competitor and willingness to pay a price premium (Cronin \& Taylor, 2007).

On the other hand, the behavioral aspect of customer loyalty represents- actual repeat purchase of products or services that includes purchasing more and different products or services from the same company recommending the company to others, and reflecting a long-term choice probability for the brand. It can be concluded that customer loyalty expresses an intended behavior related to the product or service or to the company. Customer loyalty is deemed as a vital component for enduring business success (Donnelly, 2009; Kumar, Batista \& Roger, 2011; Roberts, 2009; Srinivasan, Anderson, \& Ponnavolu, 2002). Customers who are loyal to specific products or brands do not mind being charged on a premium basis, engage in more positive words of mouth and are more hostile to competing firms' marketing communications (Mohammad, Tabriz, Chalous, \& Aras, 2013; Srinivasan, Anderson \& Ponnavolu, 2002.). "These advantages enhance business operators to develop and launch customer loyalty as the ultimate goal in their firm marketing strategy".

However, some scholars emphasised customer loyalty towards particular brands (Ali, Moradi, Arash, \& Javad, 2013; Roberts, 2009; Srinivasan, Anderson \& Ponnavulo, 2002). Other researchers defined customer loyalty by either using the focused or the behavioural method (Cunningham, 1966; Kahn, Kalwani, \& Morrison, 1986; Tellis, 1988) or by combining an attitudinal element with consumer behaviour (Srinivasa et al., 2002). However, the primary area of disagreement involved defining customer loyalty by either basing it mainly on behavioural outcomes (Cunningham, 1966; Kahn et al., 1986; Tellis, 1988)" or attitudinal outcomes (Ali, Moradi, Arash, \& Javad, 2013; Roberts, 2009; Oliver, 1999; Srinivasa et al., 2002).

Oliver (1997) described attitudinal customer loyalty as a strong hold of pledge to re-purchase or patronise a preferred product or service constantly in the future, in so doing leading to recurring same-brand or same brand-set buying. This behaviour occurs regardless of situational influences and marketing efforts which could stimulate a switching behaviour. 
However, some scholars have emphasised that in creating a strong customer loyalty and attitudinal component of the portion of the consumer is compulsory in relation to the customer's purchasing behaviour (Chaudhuri \& Holbrook, 2001; Jacoby \& Chestnut, 1978; Oliver, 1999; Roberts, 2009). In such situation, it seems sensible to deduce that the consumer's attitudinal nature would contribute towards a more positive evaluation of the product or brand over others such as retail outlets. This creates a favourable attitude towards a particular brand that forces a person's purchasing behaviour. If a customer's behaviour is inclined to be more reliable and projecting in favour of the preferred product or brand. In addition, the firm can expect other supplementary aforesaid benefits linked to customers' attitude towards loyalty on the portion of these buyers or users. In a nutshell, one can deduce comparative view point towards particular merchandiseis forceful, then the consumer purchasing that customer loyalty is an indicatorof store loyalty.

Researchers in customer loyalty has studied customer loyalty in areas such as loyalty in banking ( Auka et. al., 2013; Ball et al., 2003; Baumann et al., 2004; Beerli \& Quintana, 2004; Caruana, 2002; Filip et al.,2009; Hafeez \& Muhammad, 2012 ; Larai, 2009; Lee \& Cunningham, 2001; Menon \& O'Connor's report, 2007; Pont \& Mc Quilken, 2004; Szuts \& Toth, 2008; Titko \& Lace, 2010; Veloutsou et al., 2004) hotel industry (Kandampully \& Suhartanto, 2000; Guzzo, 2010; Lee et at., 2003; Poku et al., 2013; Ramzi \& Mohamad,2010; Stone et al,.2013 and Torres \& Kline, 2006 ) retail industry (Mustafa, 2011; wong \& sohal, 2003 and Yan \& Yoo-Kyoung, 2008) and education industry (Helen \&Wong, 2010; Intrepid Learning Solutions, 2010; Robert M Brown, 2006).

In addition, some of these studies were conducted on online shopping behaviour (Yan \& Yoo-Kyoung, 2008). Other researchers conducted a comparative study in which different service industries were compared in an attempt to find out whether individual differences appear due to the difference in the service industry (Bei \& Chiao, 2006). Some other studies were conducted on loyalty to a retail store in general without a focus on a particular type of retail (Thomas, 2013). The scientific literature illustrates a multiplicity of attempts to empirically analyse customer loyalty programmes in organisations like shopping centres (Gomez et al., 2006; Lacey, 2009), sports clubs (Daryanto et al., 2006), grocery shops (Meyer-Waarden, Benavent, 2009), restaurants (Jang, Mattila, 2005), book-shops (Wendlandt, Schrader, 2007) and others following the sample of customer oriented business. Attempts are also observed to analyze loyalty programmers in the business-to business sector (Lacey, Morgan 2009). However, there are few studies on the grocery stores in shopping malls in Saudi Arabia.

On the relationships, the findings are mixed. In banking industry those authors (cited above) tested factors that significantly affect customer loyalty such as distinctive experience, service quality, customer satisfaction, profitability, productivity, loyalty program, market characteristics, commitments, causal relationships, switching costs, trust, communication, transaction costs, interpersonal bonds, environment of bank and customer retention. The findings show that some factors such as service quality, demographic characteristic, customer satisfaction, price, image, advertisement, lifestyle, environment and structure of institutions, trust, relationship commitment, relationship marketing have significant impact on customer 
loyalty.

On the contrary, Castelo, (1999) found that Service quality and satisfaction had no statistical significance in determining service loyalty. Wong, C.B. (2005) as mentioning that customer satisfaction, which has become nothing more than the price of entry to a category is therefore the starting point to build customer loyalty. However, customer satisfaction in itself does not guarantee loyalty because in some cases $65 \%$ to $85 \%$ percent of customers who defect to competitors brands say they are either satisfied or very satisfied with the product or service they left (Reichheld, 1990; Sivadas \& Baker-Prewitt, 2000 ; Storbacka and Lehtinen, 2001).

\section{Antecedents of customer loyalty}

Researches have been accomplished on customer loyalty for their possible antecedents in forming strong relationships with consumers. The antecedents to retail loyalty include a number of factors.

Various factors have been studied in determining customer grocery retail loyalty. Among the most salient factors studied are customer satisfaction, service quality and role of sales people (Pandey \& Darla, 2012). Previous studies on service quality recommended that, retail loyalty between two types of retailers should be more or less similar. In addition, service quality has a propensity to be less standardized than product quality. As a result, it is difficult to get an equivalent level of service quality neither between retailers nor within the identical retailer on a progressing basis (Yuen \& Chan, 2010).

This study does not take into account the role of sales people as a precursor loyalty within the retail industry. This is partly due to the fact that several theoretical causes. Initially, it has been argued that the duty of sales staff in creating retail store loyalty is significantly dependent on merchandises that are distinctively multifaceted, costly, specialty items, or unsought items (Lamb, Hair, \& McDaniel, 2006).

However, in so far as this study is concerned, the retailers normally do not offer products that are in tandem with these criteria. Wong and Sohal (2003) discovered that in establishing the outcome of quality of services on customer loyalty can be observed at two levels namely the level of sales personnel and also the company. It has been discovered that the service quality at the level of the company proved to be considerably greater in establishing customer loyalty in comparison to service quality at the salesperson rank. One of the grounds is of arguments is that consumers might perceive sales people as a depiction of the business provider and not as a distinct entity.

In addition, Poujol and Pellet (2012) as well as Wong and Sohal (2003), argued that sales person loyalty is a precursor to company loyalty. Hence, the scholars strongly argue that the level of loyalty of the consumers is extremely high to his sales person; he will also be highly loyal to the business that hires that sales person. Therefore, sales person loyalty is redundant in this research as sales people are not considered as persistent characteristics of a retail store. For that reason, if a consumer frequents a retail store it is mostly due to the fact that he/she has established a trust worthy rapport with the store sales person, he/she could not be truly loyal to the retail store itself, but merely to the sales person. This situation indicates an 
unreliable or spurious loyalty whereby a consumer who is loyal to the sales person and not a retail store may one day decide not to continue shopping at a retail store if the sales person were to leave his/her position.

Finally, the justification why sales people are not the main focus of the current study is because it has been argued that most consumers purchase products or services not based on the said rapport as many are not interested in developing interpersonal relationships with sales people. This opinion was supported by a study initiated by Macintosh and Lockshin (1997) where they found that only $38 \%$ expressed the necessity to establish an interpersonal relationship with sales people. This justifies why including sales people in this current research would not be relevant to the considerable number of respondents. The Saudi buyer's interest, trust, the customer's loyalty, quality of service and items provided in grocery stores in shopping malls are main issues. There is also a lack of actual research on the service quality perceived by purchaser and customer's loyalty regarding their grocery shopping experiences in Saudi Arabia (Metrology and Quality Organization, 2012).

The following table (Table 2.1) represents a summary about some of the research studies that have been conducted on loyalty together with the antecedent factors that have been proposed and examined.

Literatures indicate that studies on perceived service quality are mostly conducted in the Western and Eastern countries, but only a few were conducted in the Middle East, particularly Saudi Arabia. As a result, our interpretation on the service quality perceived by customers and the factors that influence the provision of this service quality is somehow of the narrow view. This suggests the need for further investigation (Rahman, 2012).

\section{Customer Satisfaction}

Customer satisfaction is a well-known and established concept in several areas like marketing, consumer research, economic psychology, welfare-economics, and economics. The most common interpretations obtained from various authors reflect the notion that satisfaction is a feeling which outcome of the process of evaluating what has been received against what was expected, including the purchase decision itself and the needs and wants associated with the purchase. However, satisfaction is the customers' evaluation of a product or service in terms of whether that product or service has met their needs and expectations (Bitner \& Zeithaml, 2003). According to Boselie, Hesselink, and Wiele (2002) satisfaction is a positive, affective state resulting from the appraisal of all aspects of a party's working relationship with another. Hence, the concept of customer satisfaction has aroused the attention of academics and practitioners for more than thirty years as customers are said to be the primary source of most firms' revenue. In the early 1960, Cardozo (1965) firstly introduced the concept of customer satisfaction into the field of marketing. Thereafter, many scholars started to research on this concept. According to Cengiz (2010), customer satisfaction is a key issue for all organizations that wish to create and keep a competitive advantage in today's highly competitive world. Therefore, it was precise when Czepiel and Rosenberg (1977) stated three decades ago that there is probably no concept in marketing that is at once more fundamental and pervasive than consumer satisfaction. 
Literature of customer satisfaction reveals that the definition of customer satisfaction can be categorised according to three perspectives: (1) disconfirmation model theory; (2) transaction costs theory; and (3) transactional-specific theory.

Furthermore, regarding the links among variables, there are different arguments about the link between customer loyalty, customer satisfaction and service quality. There is a link between products, services' quality and customer satisfaction which are an important determinant of store loyalty (Oliver, 1999 ; Rahim, Osman, \& Ramayah, 2010; Wallace, Giese, \& Johnson, 2004). The findings of the literature about the service quality, and customer satisfaction are better predictors for customer loyalties (Bolton \& Drew, 1991 ; Cronin \& Taylor, 1992) remain inconclusive. One group of the researchers believes that customer satisfaction is antecedent to service quality (Beerli, Martin, \& Quintana, 2004; Bitner, 1990; Bolton \& Drew, 1991; Brady \& Robertson, 2001; Dabholkar, 1995; Winstanley, 1997). Another group of researchers believes that service quality affects store loyalty through the mediating influence of customer satisfaction (Balaji, 2009; Bedi, 2010; Kassim \& Abdullah, 2010; Kumar, Kee, \& Charles, 2010; Lee \& Hwan, 2005; Naeem \& Saif, 2009; Yee, Yeung, \& Cheng, 2010 ). A third perspective maintains that there is a direct relationship between service quality and store loyalty (Taylor \& Cronin, 1994). Perceived service quality, customer satisfaction, and store loyalty all are interlinked (Oliver, 1999; Rahim, Osman, \& Ramayah, 2010; Wallace, Giese, \& Johnson, 2004).

Haque, et al., (2012) found that Personal support strongly impacted customer satisfaction. Hospital services acted as mediator. No significant relationship was detected between attention to customer and customer satisfaction. The researcher just reports the results but don't provide the enough justification about the significant relationship between attention to customer and customer satisfaction.

In the literature on customer satisfaction in the retail industry in general and grocery retail in particular, there are a significant amount of research on the construct of customer satisfaction and how this is connected to perception about services quality. These studies are founded on the construct of customer satisfaction in various service-oriented industries such as banking (Al-Hawari \& Ward, 2006; Hafeez \& Muhammad, 2012; Larai, 2009; Szuts \& Toth, 2008; Titko \& Lace, 2010; ) hotel industry (Kandampully \& Suhartanto, 2000; Lee et at., 2003; Poku et al., 2013 ; Torres \& Kline, 2006) education industry (Brown, 2006). Others were conducted on internet use (Wu \& Chan, 2011) while other studies were carried out on the retail industry in general without a specific focus on a particular type of retail (Yuen \& Chan, 2010).

The findings show that some factors such causal relationships, Image, perceived quality, switching costs, customer relations, human resource management, customer service management and low price have the significant impact on customer satisfaction. Castelo, (1999) found that Service quality and satisfaction had no statistical significance in determining service loyalty. Wong, (2005) cited Clarke (2001) as mentioning that customer satisfaction, which has become nothing more than the price of entry to a category is, therefore, the starting point to build customer loyalty. However, customer satisfaction in itself does not 
guarantee loyalty because in some cases $65 \%$ to $85 \%$ percent of customers who defect to competitors brands say they are either satisfied or very satisfied with the product or service they left (Reichheld \& Sasser, 1990; Sivadas, \& Baker-Prewitt, 2000; Storbacka \& Lehtinen, 2001).

There is an agreement on the link between perceived service quality, customer satisfaction, and store loyalty (Oliver, 1999; Rahim, Osman, \& Ramayah, 2010; Wallace, Giese, \& Johnson, 2004). However, there is no consensus among researchers on the nature of the links between these variables particularly on the causal ordering of service quality and customer satisfaction. The non-conclusive findings of the mentioned relationships show that the impact of service quality and customer satisfaction on customer loyalty is complex. Tor Wallin Andreassen, Bodil Lindestad, (1998) found that corporate image impacts customer loyalty directly whereas customer satisfaction does not. This finding was consistent with high and low service expertise. These results challenge the dis confirmation paradigm which predicts customer satisfaction as the primary route to customer loyalty. So, the findings of previous studies are mix on the relationship between customer satisfaction and customer loyalty.

In short, we are not sure whether the mediating affect of customer satisfaction will exist between the relationship of customer loyalty, perceived service quality and customer satisfaction. Laraqui (2009 stated that further studies should test the relationship between the customer satisfaction and customer loyalty. The present study responds to the recommendation and focuses on grocery retail as, there are few researches attempted to explore mediating role of customer satisfaction in grocery retail environment, particularly in the Arab countries.

Furthermore, there is an agreement on the link between perceived service quality, customer satisfaction, and store loyalty (Oliver, 1999; Rahim, Osman, \& Ramayah, 2010; Wallace, Giese, \& Johnson, 2004). However, there is no consensus among researchers on the nature of the links between these variables particularly on the causal ordering of service quality and customer satisfaction. The non-conclusive findings of the mentioned relationships show that the impact of service quality and customer satisfaction on customer loyalty is complex, and it merits further investigation.

\section{Perceived Service Quality}

Traditionally, service quality has been conceptualized as the difference between customer expectations regarding service to be received and perceptions of the service being received (Grönroos, 2001). It is considered difficult to define quality (Lagrosen, 2004). However, a clearer picture has been offered by ISO 9000: 2000, in which quality has been defined as a scaleto which a group of in-built features fulfils conditions. Furthermore, anything perceived important by consumers are indicative of several probable aspects of quality (Clemes, Gan, Kao, \& Choong, 2008), which is also characterized as an assessment of service in general (Ismail, Abdullah, \& Francis, 2009). As such, when customer expectations are met or surpassed, it can be inferred that a positive perception has occurred about quality creating lasting effects in the consumer's mind (Tuan, 2012). 
However, it is comparatively easier to assess the quality levels of goods using certain technical criteria, but service quality offers Challenges in its measurement due to its predominant links with several factors that can be critical to the success. Although service quality has been termed differently by different researchers (Haque, Sarwar, Yasmin, Anwar, \& Nuruzzaman, 2012), it is generally conceptualized as zero defects, following Crosby (1980).

In addition, Juran (1980) opined that the quality is measurable through internal and external breakdown. However, these kinds of distinctions that exist in the manufacturing sector are difficult to get imitated in the service sector (Haque et al., 2012). In the context of the service sector, a sense of balance between what customers expect and what they are offered in terms of service is considered a major criterion to measure service quality (Lewis \& Booms, 1983).

However, the consumer's evaluation about the distinction or dominance of business can be termed as perception about services quality (Parasuraman, Zeithaml, \& Berry, 1988) which can be further simplified by calling it an evaluation by a consumer who through his/her encounter conducts an evaluation between their service expectations and the actual service offered to them (Jiang \& Wang, 2006). Perception about services quality is usually can be briefly defined as 'the extent to which service delivery is able to match up with or exceed the expectations of consumers' (Laroche, Ueltschy, Abe, Cleveland, \& Yannopoulos, 2004). Perceptions related to service quality are also said to be a global judgment or in other way an attitude pertaining to the service's superiority (Kumar, Mani, Mahalingam, \& Vanjikovan, 2010; Zeithaml \& Bitner, 2003). As such, superior service quality primarily seeks to build trust among buyers as well as sellers and therefore plays an integral role in the formation of consumer choices (Liu, Guo, \& Hsieh, 2010).

Customer evaluations of service quality do not totally depend on service attributes; instead, they also take into consideration other aspects like the feelings or memory of the customer (Jiang \& Wang, 2006) and as such it can be inferred that facility quality is calculated by the customers in terms of the pleasure they derive from a particular service (Malik, 2012). This is in line with Dabholkar's (1996) study that compared alternative service delivery options where he found that customer evaluations of an option and intention to use that option increased due to the potential enjoyment derived from that particular option. Enjoyment, reliability and perceptions regarding speed of delivery had also been found to be significantly impacting service quality perceptions (Shamdasani, Mukherjee, \& Malhotra, 2008).

Customer-perception about services quality has been assessed so far using the following renowned methods: (1) SERVQUAL, which stresses on the comparison between customer's prior expectations and the services, received (Parasuraman et al., 1988); (2) SERVPERF, which deals only with service quality perceptions (Cronin \& Taylor, 1992); (3) EP, which elucidates the differences between quality perceptions and customer-desired state (Teas, 1993); and (4) HSQM, which focuses on using service quality as a multi-level construct with three dimensions namely communication quality, settingquality and result quality (Brady \& Cronin, 2001). The SERVQUAL method is clustered into five service elements: tangibles, dependability, alertness, promise and understanding. 
However, the quality perceptions of customers can also be based on several other factors which are yet to be investigated and the earlier models of perceived quality and satisfaction are now posed with a number of drawbacks mostly because, overall environment and knowledge level related to perceived quality as well as satisfaction have all improved with changing times and consequently there is a need to update the knowledge on these two (Purgailis \& Zaksa, 2012).

In general, perceived service quality has been found to be driving the perceptions and behaviour of customers significantly. In that regard, merchandise quality, prices and service quality play a significant role in driving perceived worth which further leads to customer loyalty (Parasuraman \& Grewal, 2000; Zeithaml, 1988).

It is also important to point out that it is easier to imitate merchandise quality and prices but it is hard to replicate the service quality aspects ( $\mathrm{He} \& \mathrm{Li}, 2011)$, which is why this research considers perception about services quality as an important aspect for further scrutiny. Furthermore, there are several other issues related to its formation which are not yet clarified (Urban, 2010). For instance, several studies conducted in different countries indicate that there exists a consequence of perceived service quality on customer satisfaction and store loyalty (Al-Hawari \& Ward, 2006; Bei \& Chiao, 2006; Malik, Naeem, \& Arif, 2011; Mosahab et al., 2010).

However, this study extends the issue further by investigating several antecedents and consequences of perceived service quality in a single model, unlike previous researchers that tended to look at the perceived service quality formation issues separately. Indeed, researchers have highlighted that in the marketing literature, perceived service quality has emerged as one of the most important, yet unsettled constructs (Laroche, Ueltschy, Abe, Cleveland, \& Yannopoulos, 2004).

Oliver (1996) asserts that perceived service quality serves as an input to both customer satisfaction as well as worth, which have an effecton the loyalty of the customers (Mohammad et al., 2013). Prior to actual consumption encounter, customers are said to possess a range of expectations based on their past encounters or from advertising/word of mouth which in turn serve as a benchmark for interpreting quality at the point of service offering (Laroche et al., 2004).

\subsection{Dimensions of Perceived Service Quality}

Knowing service quality perceptions and the influence of these perceptions on the behaviour of customers has remained a critical issue affecting business performance and the long-term viability of the firm (Carrillat, Jaramillo, \& Mulki, 2007; Kim, Kim, \& Lee, 2011) which is why this research endeavours further to understand the service quality perception aspect by examining its determining factors, as elaborated below.

\subsubsection{Physical Aspects}

Customers seem to give great importance to the physical aspects while pursuing their shopping activities in retail outlets. Supporting factors in terms of physical services are 
related to both environments and capacities, and they also include the kinds and friendliness of employees' interaction with their customers (Raza, Siddiquei, Awan, \& Bukhari, 2012). According to Parasuraman et al. (1988), an organisation's physical environments are part of the tangibles dimension that covers various kinds of services, equipment, and materials for communication. However, the physical amenities and staff appearance often give rise to the largest incongruity between expectation and perception (Urban, 2010) although it unanimously agrees that physical environments must be supportive and convenient for the customers (Tuan, 2012) for them to have a favourable perception of service quality.

\subsubsection{Reliability}

Reliability in the retail sector refers to the time liness and precision of service employees' ways of handling customer issues and meeting their promises to the customers $(\mathrm{He} \& \mathrm{Li}$, 2011). It can immensely affect the service quality perception of customers. Early research suggested reliability as one of the significant attributes on which customers form their expectations on service quality (Dabholkar, 1996). Moreover, reliability as per (Parasuraman, Zeithaml, \& Berry, 1988) is a fundamental driver for the overall service quality which relates to the establishment's capacityto implement the undertaken pledge to provide services in an accurate as well as dependable manner.

\subsubsection{Confidence}

The service quality perception of customers is largely dependent on the ability of employees in instilling confidence among their customers. It also is linked with the employees' aptness in understanding customer needs and the quantum of knowledge they possess for answering the questions of the customers (Kumar, Mani, Mahalingam, \& Vanjikovan, 2010). In order to be in line with customer's expectations, service workers need to allocate appropriate time to serve their customers in order to enhance their confidence (Haque, Sarwar, Yasmin, Anwar, \& Nuruzzaman, 2012). Moreover, ability to gain trust and confidence has been part of assurance that is one of the key aspects proposed in Parasuraman et al., (1988) model Sellers need to offer all kinds of assurance to their customers so that these customers are at ease when making their merchandise selection. On the contrary, any failure to do so may lead to an adverse impact on customer confidence (Liu, Guo, \& Hsieh, 2010).

\subsubsection{Helpfulness}

Customer service quality perception can be affected by the way service workers deal with them. Helpfulness is in line with responsiveness according to Parasuraman et al., (1988) model that indicates the willingness and enthusiasm of service staff in offering responsive and helpful service (Urban, 2010). Cooperative and helpful staff leads an organization towards winning customer confidence which in turn leads to enhancing their perception towards that organization's service quality (Haque, Sarwar, Yasmin, Anwar, \& Nuruzzaman, 2012). The longer service is used by the customers, the more frequent and consistent service is perceived by them from the service staff and this perception is sustained by the customers during every visit (Urban, 2010). As such, it is the responsibility of the service staff to stay helpful throughout the encounter of customers in an appropriate manner. 


\subsubsection{Problem Solving}

To create a positive and stronger perception regarding service quality among customers, services must be offered by personnel who are professionally competent, who can act as advisors to their customers, and who always focus on problem solving (Gummesson, 1978, p. 90). It was found that customer satisfaction is enhanced by different aspects of service quality like problem handling and credibility (Malik, Naeem, \& Arif, 2011; Siu \& Mou, 2005). Moreover, a service provider is expected to stay proactive in terms of relationship building with the customers so that it knows on an on-going basis what problems are persisting and how they can be fixed without disturbing, stressing, or embarrassing the buyer (Melville, 1999, p. 70).

\subsubsection{Policy}

Company's policies have got a considerable say in facilitating a customer's perception about service quality. It has been suggested that an effective and steady marketing policy can stimulate future customers and further enhance the customer's service quality perceptions in addition tothe revenue of organisations (Haque, Sarwar, Yasmin, Anwar, \& Nuruzzaman, 2012). Similarly, effective operational policy can lead an organization towards offering the best service quality performances which in turn can help it build a strong brand image (Gursoy, Chen, \& Kim, 2005; Kim, Kim, \& Lee, 2011). Service quality is also based on the extent of personal relationships which can be ensured by avoidance of improper human resource policies by companies particularly some situations like rapid staff exchange (Urban, 2010). Even the compensation policies of firms that take into account the interest of the buyer as well as the seller may have an impacton the formation of perceptions about service quality among the customers (Jun, Yang, \& Kim, 2004; Liu, Guo, \& Hsieh, 2010; Yang \& Jun, 2002).

Based on the discussion above, this current research contends that the perception about services quality can be affected by the abilities of organisations to handle and deal with issues like physical aspects, reliability, confidence creation, helpfulness, problem solving and policy.

\section{Customer Satisfaction is an Antecedent to Service Quality}

Many scholars have argued that customer satisfaction dictates service quality (e.g., Bitner 1990; Bolton \& Drew 1991). They argued that customer satisfaction represents an antecedent to service quality (Bolton \& Drew, 1991; Carman, 1990). In this context, the authors reasoned that customer pleasingen counter may have a positive impact on customer attitude and coherently his or her assessment of perception about services quality. Therefore, customer satisfaction with a specific deal may result in positive global assessment of service quality (Holjevac, Markovic, \& Raspor, 2013). In elaborating this argument, Brink and Berndt (2008) based their thesis of the argument on the definition of the service quality itself. The authors defined service quality as the ability of an organisation to determine customer expectations correctly and to deliver the service at a quality level that will at least equal customers' expectation. Based on that definition, it is argued that an organization can only meet its 
service quality when their customers are satisfied with the level of services rendered.

Adigun (2004) supported this proposition. He asserts that the level of service quality can be measured mainly by asking customers to rate the service they received. In other words, customer satisfaction remains the indicator to the determination of service quality, and therefore, the direction of causality is from customer satisfaction to service quality. Parasuraman, Zeithaml, and Berry (1988) agreed with this finding by positing that satisfaction is more transaction specific and that incident of satisfaction over time results in perceptions of service quality. Finally, a number of researchers (Beerli, Martin, \& Quintana, 2004; Bolton \& Drew, 1991; Bloemer \& Ruyter, 1998; Owolabi, 2001) all supported the views of Brady and Robertson (2001), Adigun (2004) and Parasuraman et al. (1994) that customer satisfaction leads to service quality.

\section{Service Quality Affects Store Loyalty through the Mediating Influence of Customer Satisfaction}

While there are different arguments and propositions on the causality of the link between service quality and customer satisfactions, the proponents of the group that argues service quality affects store loyalty through the mediating influence of customer satisfaction tend to receive the most support (Balaji, 2009; Bedi, 2010; Kassim \& Abdullah, 2010; Kumar et al., 2010; Lee \& Hwan, 2005; Naeem \& Saif, 2009; Yee, Yeung, \& Cheng, 2010). The strongest support comes from leading service quality scholars i.e. Parasuraman, Zeithaml, \& Berry $(1985,1988)$. They viewed that service quality results in customer satisfaction. They argued that since customer satisfaction is an affective state, and service quality is a cognitive state, cognition precedes emotions in the causal chain of psychological processes rests on a solid theoretical ground (Oliver 1997).

In addition, Spreng and Mackoy (1996) while studying the relationship between service quality and satisfaction tested Oliver's model in which the relationship between service quality and customer satisfaction is explained. The researchers concluded that service quality leads to customer satisfaction. This group of authors suggests that service quality is a cognitive evaluation, which may lead to satisfaction (Jamali, 2007; Zeithaml\&Bitner, 2003). Therefore, service quality was considered as an antecedent of customer satisfaction.

In addition, the service quality to customer satisfaction chain-of-effects has also found ample empirical support across numerous service settings (e.g., Cronin \& Taylor 1992; Fornell 1992; Gotlieb, Grewal, \& Brown 1994; Kim, 2011; Olsen 2002). On top of that, compelling evidence is also provided by findings of Dabholkar, Shepherd, and Thorpe's (2000) longitudinal study, which showed that service quality precedes customer satisfaction.

Research work in this field affirms the importance of service quality as is a fundamental gaugeof customer satisfaction (Spreng \& Mackoy, 1996). In addition, Mittal and Lassar (1998) state that research work in the field of service quality has recently begun to tackle whether or not service quality differentially influences satisfaction depending on particular service settings or situations (Mittal \& Lassar, 1998). This idea of quality/satisfaction processes operating under different conditions is relatively well accepted in the case of 
tangible goods (e.g. Cengiz, 2010; Churchill \& Surprenant, 1982; Tse \& Wilton, 1988). However, not much research has been done to test if the same applies to services (Prabhakar \& Ram, 2013).

Finally, customer satisfaction has been hypothesised to be an important antecedent in fostering customer retention (Gil, Hudson, \& Quintana, 2006) since it can influence a purchaser's decision to continue their relationship with the organisation or the service provider (Ndubisi, Malhotra, \& Chan, 2009). Magi \& Julander, (2009) studied that among grocery stores in Sweden showed a positive relationship between perception about services quality, customer satisfaction and customer loyalty. It was shown that customer satisfaction resulted from high perception about services quality, and this made customers loyal. Yeung et al. (2002) and Luo and Homburg (2007) concluded that customer satisfaction positively affects business profitability. Studies that have investigated customer behaviour patterns (Chi \& Qu, 2008; Dimitriades, 2006; Faullant, Matzler, \& Fuller, 2008; Kandampully \& Suhartanto, 2000; Olorunniwo, Hsu, \& Udo, 2006; Soderlund, 1998) found that customer satisfaction increases customer loyalty, influences repurchase intentions and leads to positive word-of-mouth. However, in te case of saoudi Arabia, , there are studies conducted in the general retail industry in Saudi Arabia, and they do not attempt to draw a connection between the service quality perceived by Saudi customers and their loyalty to the store (Mustafa, 2011).

Thus, it could be seen that research studies reported different views on the nature of causal links between the three constructs of service quality, customer satisfaction and customer loyalty. Specifically, one group reported a direct relationship between service quality and loyalty while another group reported a mediating influence of customer satisfaction on the relationship between service quality and customer loyalty when a third group believed that customer satisfaction is an antecedent to service quality. This clearly indicates that the nature of links between the three variables is complex and in need for further analysis and validation. Thus, this study attempts to validate these different views by examining the various relationships between them.

Consequently, it could be seen that most of these studies on perceived service quality were conducted on other sectors such as banking (Auka et. al., 2013; Filip et al.,2009; Fragata, 2009; Hafeez \& Muhammad, 2011; Kazi Omar Siddiqi, 2011; Lee et at., 2003; Rahim Mosahab, 2011; Szuts \& Toth, 2008 \& Titko \& Lace, 2010), car industry (Samani et al., 2011) hotel industry (Hansen et al., 2010; Poku et al., 2013; Stone et al., 2013) retail industry (wong \& sohal, 2003) and education industry (Intrepid Learning Solutions, 2010; Robert Brown, 2006). The researcher didn't find any study that examine the mediating affect of customer satisfaction on the relationship between customer loyalty and perceived service quality particularly in grocery stores in shopping malls in Saudi Arebia. Furthermore, the relationship among different variable cannot be taken for granted in the context of different countries since culture and background differ across countries (Donthu \& Yoo, 1998; Imrie, Cadogan, \& McNaughton, 2002). There are studies conducted on the general retail industry in Saudi Arabia, but they do not attempt to draw a connection between the service quality perceived by Saudi customers and their loyalty to the store (Mustafa, 2011).So, there is the 
need for further investigation.

In the reference of a relationship, the findings are mixed on the relationship between the customer satisfaction customer loyalty and the relationship between the perceived service quality and customer satisfaction. Service quality and as well as customer satisfaction are distinct concepts, closely related, and yet the exact nature of these customer acumens and the relationship between them remains unclear (DeRuyter et al., 1997; Prabhakar \& Ram, 2013).

Castelo, (1999) found that service quality and satisfaction had no statistical significance in determining service loyalty. Wong, (2005) cited Clarke (2001) as mentioning that customer satisfaction, which has become nothing more than the price of entry to a category is therefore the starting point to build customer loyalty (Reichheld \& Sasser, ,1990; Sivadas \& Baker-Prewitt,2000; Storbacka \& Lehtinen, 2001). Some studies show a positive relation between perceived service quality, customer satisfaction and customer loyalty. Perceived service quality influences the level of customer satisfaction (Parasuraman et al., 1994; Rust \& Keiningham, 1996) which in turn has an impact on customer loyalty (Hallowell, 1996; Harris \& Goode 2004; Rust \& Keiningham, 1996), it can be postulated that perceived service quality also influences customer loyalty (Bei \& Chiao, 2001; Cronin, Brady \& Hult, 2000; Mohammad et al., 2013;)

Furthermore, there are studies conducted on the general retail industry in Saudi Arabia, but they do not attempt to draw a connection between the service quality perceived by Saudi customers and their loyalty to the store (Mustafa, 2011). Although service quality and customer loyalty is linked through the mediating influence of customer satisfaction, as suggested by the literature, this relationship cannot be taken for granted in the context of different countries since culture and background differ across countries. (Donthu \& Yoo, 1998; Imrie, Cadogan, \& McNaughton, 2002).

Taking into account that most of the previous research studies on these links in grocery retail context have been conducted in Western and Eastern countries, the findings of these studies may not be applicable in the Middle Eastern country like Saudi Arabia, which is characterised by distinct culture as compared to most countries around the world. The culture and lifestyles of Saudi consumers of grocery shopping are different from most countries in the world and it is even different from many neighbouring Arabic countries. An example about these differences in the Saudi culture could be seen in the country's strict rules that do not allow forms of entertainment and amusement activities such as cinemas and music and songs inside public places. This could highly influence the nature of the Saudi shopping experience and may give different and probably contradictory findings to the ones reported in previous research studies.

\section{Perceived Service Quality Studies in Saudi Arabia}

AlGhamdi, Drew, and Ghaith (2011) conducted a study that aimed at looking into the diffusion of the adoption of online retailing in the context of Saudi Arabia in which 16 retailers' views about the adoption of electronic retailing systems were examined. However, the study attempted to examine aimed to focus on diffusion of the adoption of online retailing 
in Saudi Arabia from the retailers' perspectives. For the purpose of the study, a sample of retail sector decision makers in Saudi Arabia participated in the study. Both positive and negative issues influencing retailer adoption of electronic retailing systems in Saudi Arabia were identified. The study employed qualitative research methodology in which semi-structure interviews were conducted to collect the data.

A number of impediments which included cultural, business and technical issues were reported in the study. In addition, facilitating factors included access to educational programs and awareness building of e-commerce, government support and assistance for e-commerce, trustworthy and secure online payment options, developing strong ICT infrastructure, and provision of sample e-commerce software to trial. The findings of the study revealed a number of perceived impediments relating to cultural, business and technical issues. Apart from that, the findings of the study also highlighted several potential facilitators of retailer adoption of e-retailing practices that will aid the development towards the e-retail growth in Saudi Arabia. The researchers recommended that policy makers and developers in the country ought to pay attentions to these factors as this aids in facilitating e-retail growth in KSA.

The findings and objectives of AlGhamdi, Drew, and Ghaith's (2011) study are significant for the purpose of the current study as their study attempted to examine the perceptions about retailing but from the perspective of retailers themselves rather than examining the perceptions of customers. It has been mentioned earlier that one of the problem with many retailers is that they assume what is good and bad for their customers and based on these assumptions, retailers direct their marketing strategies or their merchandise formation (Liu, Guo, \& Hsieh, 2010). Liu, Guo and Hsieh (2010) further elaborate that retailers are required to constantly evaluate their services by examining the perceptions of their customers on the services provided and this would ensure securing competitive advantage and long-term survival for these retailers.

The current study is different from AlGhamdi, Drew, and Ghaith's (2011) study in the sense that the study aims at examining the perceptions on service quality from the customers' perspectives by examining the perceived service quality in the grocery retail market in Saudi Arabia. It is hoped that grocery retailers would be able to view the perceptions of their customers so that they direct their marketing strategies and services based on these evaluations by customers rather than based on their own assumptions of what customers want and desire.

Another study that was conducted by Albarq (2013) designedat evaluating the impact of service quality underlying the SERVQUAL model on customer loyalty. This effect reconciling was examined through the mediating impact of customer satisfaction. The dimensions of service quality used in the study included the following, tangibles, reliability, responsiveness, assurance, and empathy. Thus, the relationships between these dimensions and customer satisfaction, and customer loyalty were investigated. For the purpose of the study, 422 respondents were selected from five local banks in the city of Riyadh in Saudi Arabia to constitute the respondents in the study. The study employed the use of questionnaires as the study's instrument and these questionnaires were personally 
administered to the respondents. The questionnaire included questions about the respondents' demographic profile, as well as items to measure the constructs. SERVQUAL were adapted for measuring service quality. For the purpose of the analysis and drawing inferences, the study employed the SPSS software in which descriptive analysis was used to report the findings for each variable and the regression analysis was utilized to examine the relationships between the study's variables.

The finding of the study revealed that increasing service quality can indeed assist to enhance customer loyalty and empathy, assurance, and reliability are the service quality dimensions that play significant functions in this equation. However, this influence of service quality dimensions on customer loyalty is mainly done through the mediating impact of customer satisfaction. The findings of the study also indicate that while on overall the respondents evaluate the banks positively, improvements can still be made. The study recommended that future research ought to integrate new technologies as an aspectthat can be used to measure service quality. The study also suggests that studies and related questionnaires must also take into account the new banking requirements of the customer.

Ahmad (2012) conducted a study that aimed to investigate the attractiveness aspects that influence shoppers' satisfaction, loyalty, and personal recommendations in the Saudi shopping mall centers. For the purpose of the study, a purposive sampling technique was employed in which a sample of 600 shopping mall customers, representing all of the shopping malls purchasers in the city of Jeddah, Saudi Arabia was selected. In addition, structured questionnaires were distributed through personal interviews with shopping malls mangers and shops and outlets owners to collect the data. For the purpose of the analysis and drawing inferences, the study employed multiple regression analysis techniques to show the influence of shopping malls attractiveness factors on the shoppers' satisfaction.

The findings of the study showed that aesthetic, convenience and accessibility, merchandise variety, entertainment, and service quality have an influence on shopper satisfaction. The findings of the study also revealed that the most note worthy factor was merchandise variety. The study recommended that the future research should be simulated with other region and cities in KSA or other Gulf countries to further investigate the luring factors in the other industry. The study also recommended that future research should study the proposed model in service sector such as spa villages, or hotels in order to gain more substantiation for the model and additional general findings. The study also suggested that future research should investigate whether the model could be used for different dependent variables e.g. market share or profits.

Bostanji (2013) conducted a study that expected to determine the impact of service quality (quick responsiveness, empathy, and tangibility) on customer's loyalty in five stars hotels in Saudi Arabia. The population of the study consists of all hotels customers in Riyadh. To serve the objectives of the study, a convenience sample was utilised after conducting a pilot study with nearly $10 \%$ of the sample. A questionnaire that includes the 22-statement scale of service quality that was developed by (Parasuraman, Berry, Ziethmail, 1988) in which five dimensions for service quality were identified. 500 questionnaire were distributed while only 
333 were recalled accounting for $(70 \%)$ of response rate from the sample. For the purpose of the analysis and drawing inferences, the study employed the SPSS software in which Varimax analysis and Factor analysis were used.

The outcomes of the study revealed that there is a positive statistically important impact of the following hotel service quality dimensions: quick responsiveness, tangibility, empathy on hotels customer loyalty variable in Riyadh. The results of the research also specified that previous hotel service quality dimensions interpret $(57.7 \%)$ of changes in customer loyalty. The study also showed that there is no contribution of some hotel service quality dimension elements (quick responsiveness, tangibility, and empathy) equally in achieving customer loyalty, since empathy ranks the first, quick responsiveness ranks the second, and finally tangibility ranks the third in terms influencing loyalty level. As for the recommendations sections, the researcher recommended that future research studies could it conduct future studies that deal with the impact of other factors affecting customer loyalty, such as the study of the impact of customers perceived image on their loyalty level. Among the other factors that have been suggested for further examination was the impact of value obtained by customers upon using the service on their loyalty level. Finally, the study recommended that future researchers could examine the impact of internal marketing on customers' loyalty.

\section{Conclusion}

There are studies conducted on general retail industry in Saudi Arabia, but they do not attempt to draw a connection between the service quality perceived by Saudi customers and their loyalty to the store. Although service quality and customer loyalty is linked through mediating the influence of customer satisfaction, as suggested by the literature, this relationship cannot be taken for granted in the context of different countries since culture and background differ across countries.

In the previous studies, there is an agreement on the link between perceived service quality, customer satisfaction, and store loyalty. However, there is no consensus among researchers on the nature of the links between these variables particularly on the causal ordering of service quality and customer satisfaction. The non-conclusive findings of the mentioned relationships show that the impact of service quality and customer satisfaction on customer loyalty is complex, and it merits further investigation.

Literatures indicate that studies on perception about quality of the grocery retail environment have been primarily conducted in the Western and Eastern countries, but only a few were conducted in the Middle East, particularly Saudi Arabia. As a result, our interpretation on the service quality perceived by customers and the factors that influence the provision of this service quality is somehow narrow view. This suggests the need for further investigation in Middle East especially.

\section{References}

Ahmad, A. E. (2012). Attractiveness Factors Influencing Shoppers' Satisfaction, Loyalty, andWord of Mouth: An Empirical Investigation of Saudi Arabia Shopping Malls. International Journal of Business Administration, 3(6), 58-67. 


\section{Macrothink}

Journal of Entrepreneurship and Business Innovation ISSN 2332-8851

AlGhamdi, R., Drew, S., \& Al-Ghaith, W. (2011)j Factors Influencing E-Commerce Adoption by Retailers in Saudi Arabia: A Qualitative Analysis, The Electronic Journal of Information Systems in Developing Countries, 47(7), 1-23.

AlGhamdi, Rayed., Drew, Steve .,\& AlGhaith, Waleed. (2011). Factors Influencing E-Commerce Adoption by Retailers In Saudi Arabia: A Qualitative Analysis. The Electronic Journal on Information Systems in Developing Countries, 47(7), 1-23.

Al-Hawari, M., \& Ward, T. (2006).The effect of automated service quality on Australian banks' financial performance and the mediating role of customer satisfaction.Marketing Intelligence and Planning, 24(2), 127-147.

Andaleeb, S. S., \& Conway, C. (2006). Customer satisfaction in the restaurant industry: an examination of thetransaction-specific model. Journal of Services Marketing, 20(1), 3-11.

Anderson, T, W., \& Lervik, L., (1999). Perceived relative attractiveness today and tomorrow as perceiveddictors of future repurchase intention, Journal of Service Research 2,164-172.

Anderson, Erin W., \& Mary Sullivan. (1993). The Antecedents and Consequences of Customer Satisfaction for Firms, Marketing Science, 12, 125-143.

Anderson., Eugene., \& Claes Fornell. (1994). A Customer Satisfaction Research Prospectus. 41-268 in R. T. Rust and R. L. Oliver (Eds.) Service Quality: New Directions in Theory and Practice. Thousand Oaks, CA: Sage Publications.

Andreassen, T. W., \& Lervik, L. (2012).User Perception of the Quality, Value and Utility of User-Generated Content.Journal of Electronic Commerce Research, 13(4).

Andreassen, T. W., \& Lindestad, B. (1998a). The Effects of Corporate Image in the Formation of Customer sense of fulfillment, Journal of Service Marketing 1, 82-92.

Anton, J. (1996). Customer relationship management making hard Decisions with scoff numbers, Perceivedntice- hall, New Jersey, 67-79.

Armstrong, J. S., \& Overton, T.A. (1982).Estimating non-response bias in mail surveys in marketing research: Applications and problems. In Arun, K. J., Christian, P. and Ratchford, B.T. (Eds.), Marketing research applications and problems. Chichester: John Wiley.

Armstrong, J., \& Overton, T. S. (1977). Estimating Non-response Bias in Mail Surveys.Journal of Marketing Research (JMR), 14(3), 396-402.

Arnold, S. (1997). Shopping habits at Kingston department sores, wave III, three years after Wal-Mart's entry into Canada. Report no. 3, University School of Business, Kingston, July, 3(1997).

Ashman, S. M. (2000). Grocery Store Buying Behavior: Evidence from Loyalty Program Data. Journal of Food Distribution Research, 31(1), 1-8.

Awan, M.U., Ahmad, N., Raouf, A. \& Sparks, L. (2009). Total Quality Management in Developing Countries , A case of pharmaceutical wholesale distribution in Pakistan", 
International Journal of Pharmaceutical and Healthcare Marketing, 3(4), 363-80.

Babbie, Earl. (1990). Survey Research Methods. Belmont, CA: Wadsworth Publishing, 3(47).

Bagozzi, R. P. (1992). The Self-regulation of Attitudes, Intentions and Behavior.Social Psychology Quarterly, 55(1992), 178-204.

Balaji, M. (2009).Customer Satisfaction with Indian Mobile Services.IUP Journal of Management Research, 8(10), 52-62.

Ball, A. Dwayne., \& Tasaki, Lori H. (1992).The role and measurement of attachment in consumer behavior.Journal of Consumer Psychology, 7(2), 155-172.

Ball, D., Coelho, P. and Machás, A. (2003): "The role of communication and trust in explaining customer loyalty. An extension to the ECSI Model", European Journal of Marketing, Vol. 38, № 9/10, pp. 1272-1293;

Baltas, G., \& Argouslidis, P.C. (2007). Consumer characteristics and demand for store brands. International Journal of Retail and Distribution Management, 35(5), 328-41.

Barlett, J. E., Kortlik, J.W., \& Higgins, C.C. (2001). Organizational Research: Determining Appropriate Sample Size in Survey Research. Information Technology, Learning, and Performance Journal, 19(1), 43-50.

Baron, R. M., \& Kenny, D. A. (1986). The moderator-mediator variable distinction in social psychological research: Conceptual strategic and statistical considerations. Journal of Personality and Social Psychology, 51(6), 1173-1182.

Bathaee, A. (2011). Culture affects consumer behavior-Theoretical reflections and an illustrative example with Germany and Iran. Diskussionspapier, . Retrieved July, 10, 2011 from

http://www.rsf.unigreifswald.de/fileadmin/mediapool/Fakult_t/Lenz/Diskussionspapiere/02-2 011_02.pdf, 2(11), 1-32.

Baumann, C. , Burton, S. and Elliot, G. (2004): "Determinants of customer loyalty and share of wallet in retail banking”, Journal of Financial Services Marketing, Vol. 9, pp. 231-248;

Bawa., Kapil., \& Ghosh, Avijt. (1999). A model of household grocery shopping behavior.Marketing Letters, 10(2), 149-160.

Bedi, M. (2010). An integrated framework for service quality, customer satisfaction and behavioural responses in Indian Banking industry, a comparison of public and private sector banks. Journal of Services Research, 10(1), 157-172.

Beerli, A. Martin, J. and Quintana, A. (2004):“A model of customer loyalty in the retail banking market”, European Journal of Marketing, Vol. 38, № 1/2, pp. 253-275;

Beerli, A., Martin, J. D., \& Quintana, A. (2004).A model of customer sense of fulfillment in the retail banking market.European Journal of Marketing. 38(1/2), 253-275. 
Bei, L.T., \& Chiao, Y.C. (2001). An integrated model for the effects of perceived product, perceived service quality, and perceived price fairness on consumer satisfaction and loyalty. Journal of Consumer Satisfaction, Dissatisfaction, and Complaining Behavior, 14, 125-140.

Bei. L. T.,\& Chiao. Y. C., (2006). The determinants of customer sense of fulfillment: an analysis of intangibile factors in three service industries. International Journal of Commerce and Management, 16(3), 162-177.

Belk, R. W., \& Kozinets, R. V. (2005).Videography in marketing and consumer research, Qualitative Market Research an international journal, 8(2), 128-141.

Bellenger, D.N., \& Korgaonkar, P.K. (1980).Profiling the recreational shopper. Journal of Retailing, 56(3), 77-92.

Beneke.J., C. Hayworth., R. Hobson., \& Z. Mia. (2012). Examining the effect of retail service quality dimensions on customer satisfaction and loyalty: The case of the supermarket shopper. International Journal of Event Management Research, 5(1), 27-37.

Berman, B., \& Evans, J.R. (2005).Retail Management-A Strategic Approach, New Delhi, 8th ed., Pearson Education, Singapor, 628.

Berry, L.L. (2000). Cultivating service brand equity. Journal of the Academy of Marketing Science, 28(1), 128-137.

Berry, L.L., Seiders, K., \& Grewal, D. (2002).Understanding service convenience, Journal of Marketing, 66(July), 1-17.

Berry.,\& Stanley Feldman. (1985). Multiple Regressions in Practice. Newbury Park, Ca: Sage.

Beverland M.,\& Lockshin L. (2003). A longitudinal study of customers' desired value change in business-to-business markets.Industrial Marketing Management, 32(8), 653-666.

Biong, H, (1993). Satisfaction and loyalty to suppliers within the grocery trade.European Journal of Marketing, 27, 21-38.

Bitner, M. (1990). Evaluating service encounters: the effects of physical surroundings and employee responses. Journal of Marketing.54(2), 69.

Bloemer, J., Ruyter, K. and Peeters, P. (1998): "Investigating the drivers of bank loyalty: the complex relationship between image, service quality and satisfaction", International Journal of Bank Marketing, 16/7, pp.276-286;

Bloemer, J.M. M., \& Kasper, H.D.P. (1995).The complex relationship between consumer satisfaction and brand loyalty.Journal of Economic Psychology, 16, 311-329.

Bloemer., Josee., \& de Ruyter, KO. (1998). on the relationship between store image, store satisfaction, and store loyalty.European Journal of Marketing, 32(5/6), 499-513.

Bolton, R.N., \& Drew, J.H. (1991).A multistage model of customers' assessments of service quality and value.Journal of consumer research, 17(4), 375-384. 
Boshoff., Christo., \& Terblanche, Nic S (1997). Measuring retail service quality: a replication study. South African Journal of Business Management, 28(4), 123-128.

Boulding, W., Kalra, A., Staelin.,\& R., and Zeithaml, V.A. (1993). A dynamic process model of service quality: from expectations to behavioral intentions. Journal of marketing research, 30(1), 7-27.

Brady, M. K., \& Robertson, C. J. (2001).Searching for a consensus on the antecedent role of service quality and satisfaction: An exploratory cross-national study.Journal of Business Research, 51(1), 53-60.

Brady, M.K., \& Cronin Jr, J.J. (2001). Some new thoughts on conceptualizing perceived service quality: a hierarchical approach. The Journal of Marketing, 34-49.

Brink, A., \& Berndt, A. (2008).Relationhip Marketing \& Customer Relationship Management. Lansdowne, South Africa: Juta and Co Ltd.

Bryman, A., \& Bell, E. (2003).Business Research Methods.New York: Oxford University.

Bush, Alan J., Ronald F. Bush., \& Henry C. K. Chen. (1991). Method of Administration Effects in Mall Intercept Interviews, Journal of the Market Research Society, 33(4), 309-320.

Buttle, F. (1992).Shopping motives constructionist perspective.The Service Industries Journal, 12(3), 349-67.

Buttle, F., \& Coates, M. (1984).Shopping motives. The Service Industries Journal, 4(1), 71-82.

Cadotte, EW. (1987). Expectations and Norms in Models of Consumer Satisfaction. Journal Mark Res; 24(August), 305-314.

Cardozo, R.N. (1965). An experimental study of customer effort, expectation and satisfaction, Journal of Marketing Research, 24: 244-249.

Carman, J. (1990). Consumer perceptions of service quality: an assessment of SERVQUAL dimensions, Journal of Retailing, 66(spring), 33-55.

Carpenter, J.M., \& Moore, M. (2006). Consumer demographics, store attributes and retail format choice in the US grocery market. International Journal of Retail and Distribution Management, 34(6), 434-452.

Carrillat, F.A., Jaramillo, F., \& Mulki, J.P. (2007). The validity of the SERVQUAL and SERVPERF scales: a meta-analytic view of 17 years of research across five continents. International Journal of Service Industry Management, 18(5), 472-490.

Caruana Albert., Arthur H. Money., \& Pierre R. Berthon. (2000). Service quality and satisfaction - the moderating role of value.European Journal of Marketing, 34(11/12), 1338-1352.

Castelo, J. (1999): "Un examen empírico de los antecedentes de la lealtad del cliente en la banca detallista en España", Tesis Doctoral, Facultad de Ciencias Económicas y 
Empresariales, Universidad Complutense de Madrid, España;

Cengiz, E. (2010). Measuring customer satisfaction: must or not? Journal of Naval Science and Engineering, 6(2), 76-88.

Chaudhuri., Arjun., \& Holbrook, Morris B. (2001). The chain effects from brand trust and brand affect to brand performance: the role of brand loyalty. Journal of Marketing, 65(2), 81-93.

Chen, C.F., \& Chen, F.S. (2010).Experience quality, perceived value, satisfaction and behavioral intentions for heritage tourists. Tourism Management, 31(1), 29-35.

Chen, W. (2011).The influence of user-generated content on traveler behavior: An empirical investigation on the effects of e-word-of- mouth to hotel online bookings. Computers in Human Behavior, 27(2), 634-639.

Chenet, P., Tynan, C., \& Mondy, A. (1999). Service performance gap: reevaluation and redevelopment. Journal of Business Research, 46, 133-147.

Churchill., Gilbert. Jr.,\& Carol Superceivednant (1982). An investigation into the determinants of customer satisfaction. Journal of Marketing Research, 19, 491-504.

Clemes, M.D., Gan, C.E.C., Kao, T.H., \& Choong, M. (2008).An empirical analysis of customer satisfaction in international air travel.Innovative Marketing, 4(1), 49-62.

Cochran, W.G. (1977). Sampling Techniques, Third Edition, New York: John Wiley and Sons, Inc.

Cohen, J. (1988). Statistical power analysis for the behavioral sciences ( $2^{\text {nd }}$ Ed.).Hillsdale, NJ: Erlbaum Associates.

Cooper, D.R., \& Schindler, P.S. (2006). Business research methods: empirical investigation. Journal of Service Research, 1(2), 108-28.

Cronin Jr, J.J., \& Taylor, S.A. (1992).Measuring service quality: a reexamination and extension.The journal of marketing, 56(3)55-68.

Cronin Jr, J.J., Brady, M.K., \& Hult, G.T.M. (2000).Assessing the effects of quality, value and customer satisfaction on consumer behavioral intentions in service environments. Journal of retailing, 76(2), 193-218.

Crosby, Philip B. (1980). Quality is Free the art of making quality certain; New York: McGraw-Hill.

Cunningham, Scott M. (1966). Brand Loyalty What, Where, How Much? Harvard Business Review, 34(January-February), 166-128.

Curasi., Carolyn Folkman., \& Kennedy, Karen Norman. (2002). From prisoners to apostles: a typology of repeat buyers and loyal customers in service businesses. Journal of Services Marketing, 16(2), 322-341. 


\section{Macrothink}

Journal of Entrepreneurship and Business Innovation ISSN 2332-8851 2014, Vol. 1, No. 1

Czepiel, J. A., \& Rosenberg L. (1977). Consumer satisfaction: concept and measurement. Journal of the Academy of Marketing Science, 5(4), 403-411.

Dabholkar, P. A. (1995). A contingency framework for perceiveddicting causality between customer satisfaction and service quality.Advances in Consumer Research, 22(1), 101-108.

Dabholkar, P.A. (1996). Consumer evaluations of new technology based self-service options: an investigation of alternative models of service quality. International Journal of research in Marketing, 13(1), 29-51.

Dabholkar., Pratibha A., Thorpe, Dayle I., \& Rentz, Joseph O. (1996). A measure of service quality for retail stores: scale development and validation. Journal of the Academy of Marketing Science, 24(winter), 3-16.

Danaher, P. J. \& Mattsson, J. (1994). Customer satisfaction during the service delivery

Daou, s. K. (2009).Saudi Arabia's food consumption to rise 10.9 per cent through 2013, RECWorld-Wide, 28. September, 12, 2009 Retrieved from: http://www.recexpo.com/news.php?id=6815.

Darke., Peter R., \& Cindy M.Y. Chung (2005). Effects of pricing and promotion on consumer perceptions: it depends on how you frame it. Journal of Retailing, 81(1), 35-47.

Darling., John, R., \& Taylor, Raymond, E. (1996). Changes in the competitive market position of the U.S.versus Japan, 1975-1995. Competitiveness review: an international business Journal incorporating, Journal of Global Competitiveness, 6(2), 71-80.

Daryanto, A.; Ruyter, K.; Wetzels, M.; Patterson, P. G. (2006) Exercise behavior in loyalty program: the influence of regulatory focus. In: Advances in Consumer Research 34: 346-347.

Datamonitor, (2010).Saudi Arabia: Country Analysis Report - In-depth PEST Insights, Datamonitor. Retrieved from: http://reports.iptechex.com/reports/country analysis report Saudi Arabia in depth pestle insights 1.

De Moerloose, C., Antioco, M.D.J., Lindgreen, A., \& Palmer, R. (2005).Kiosk marketing: the case of the Belgian retail sector", International Journal of Retail \& Distribution Management, 33(6/7), 472-490.(ISSN 0959-0552).

Deming, W.E. (1982). Quality, productivity, and competitive position.Cambridge, MA: Massachusetts Institute of Technology, Center for Advanced Engineering Study.

DeRuyter, K., Bloemer, J., \& Peeters, P. (1997). Merging service quality and service satisfaction an empirical test of an integrative model, Journal of Economic Psychology, 18(1997), 387-406.

Dillehay, S.M. (2006). Ways to improve patient loyalty, Review of Optometry, 143, 8-8.

Dimitriades, Z.S. (2006). Customer satisfaction, loyalty and commitment in service organizations - Some evidence from Greece. Management Research News, 29(12), 782-800. dissertation, Lagos State University, Ojo, Lagos. 


\section{Macrothink}

Journal of Entrepreneurship and Business Innovation ISSN 2332-8851 2014, Vol. 1, No. 1

Donnelly, M. (2009). Building customer sense of fulfillment: A customer experience based approach in a tourism context. Bachelor of Business Studies in Marketing, (June), 205-212.

Donthu, N., \& Yoo, B. (1998). Cultural influences on service quality expectations, Journal of Service Research, 1(2), 178-186.

Eggert, A., \& Ulaga W. (2002). Customer perceived value: a substitute for satisfaction in business markets? Journal of Business and Industrial Marketing, 17(2/3), 107-118.

Eklof, J.A. (2000). European Customer Satisfaction Index Pan-European Telecommunication Sector Report Based on the Pilot Studies (1999). Stockholm, Sweden.

Ellram, L.M., La Londe, B.J., \& Webber, M.M. (1999).Retail logistics, International Journal of Physical Distribution \& Logistics Management, 29(1999), 477-494.

Eroglu, S.A., Machleit, K., \& Barr, T.F. (2005). Perceived retail crowding and shopping satisfaction: the role of shopping values, Journal of Business Research, 58, 1146-1153.

Faullant, R., Matzler, K., \& Füller, J. (2008). The impact of satisfaction and image on loyalty: the case of Alpine ski resorts. Managing Service Quality, 18(2), 163-178.

Firat, A.F., \& Dholakia, N. (1998). Consuming People: From Political Economy to Theaters of Consumption. London: Sage.

Fisk, R. P., Grove, S. J., \& John, J. (2004).Interactive service marketing.Houghton Mifflin, Boston.

Flint D.J., Woodruff R.B., \& Gardial S.F. (2002).Exploring the phenomenon of customers' desired value change in a business-to-business context.Journal of Marketing, 66(October), 102-117.

Flint, D.J., Woodruff, R. B., \& Gardial, S.F. (1997). Customer value change in industrial marketing relationships: A call for new strategies and research. Industrial Marketing Management, 26(2), 163-175.

Fornell, C., \& Wernerfelt, B. (1987). Defensive marketing strategy by customer complaint management: a theoretical analysis. Journal of Marketing Research, 24, 337-46.

Fornell, Claes, Johnson, Michael D., Anderson, Eugene W., Cha, Jaesung.,\& Bryant, Barbara E. (1996). The American Customer Satisfaction Index: Nature, purpose, and findings. Journal of Marketing, 60(4), 7-18.

Fornell, Claes. (1992). A National Customer Satisfaction Barometer: The Swedish Experience. Journal of Marketing, 56, 1-18.

Fournier, Susan. (1998). Consumers and their brands: developing relationship theory in consumer research. Journal of Consumer Research, 24, 343-373.

Fox, E., Montgomery, A., \& Lodish, L. (2004). Consumer shopping and spending across retail formats. Journal of Business, 77(2), 25-60. 


\section{I Macrothink}

Journal of Entrepreneurship and Business Innovation ISSN 2332-8851 2014, Vol. 1, No. 1

Frumkin, P. (2002). Despite woes, US hungry for Mid-east growth.Naton's Restaurant News, $36(27), 1-39$.

Fullerton, G. (2005a). The impact of brand commitment on loyalty to retail service brands.Canadian Journal of Administrative Sciences,22(2), 97-110.

Fullerton, G. (2005b). The service quality-loyalty relationship in retail services: does commitment matter? Journal of Retailing and Consumer Services, 12(2), 99-111.

Ganesan-Lim, Cheryl., Russell-Bennett, Rebekah., \& Dagger, Tracey. (2008). The impact of service contact type and demographic characteristics on service quality perceptions. Journal of Services Marketing, 22(7), 550-561.

Gil, S.M., Hudson, S. \& Quintana, T.A. 2006. The influence of service recovery and loyalty on perceived service quality: a study of hotel customers in Spain, Journal of Hospitality and Leisure Marketing, 14(2), 47-68.

Gilbert, F. W., \& Warren, W. E. (1995).Psychographic constructs and demographic segments.Psychology and Marketing, 12, 223-237.

Gonzalez., Fernandez, A., \& Bello, L. (2002). The construct lifestyle in market segmentation: the behaviour of tourist consumers. European Journal of Marketing, 36(1/2), 51-86.

Goswami, P. \& Mishra, M.S. (2008). Would Indian consumers move from kirana stores to organized retailers when shopping for groceries? Asia Pacific Journal of Marketing and Logistics, 21(1), 127-143.

Goswami, P. (2007). Psychographic segmentation of college-goers of Kolkata. IIMB Management Review, 19(1), 41-53.

GRDI Report. (2010). Expanding Opportunities for Global Retail Development Index, 1-15.

Gremler, D. D. (1995):“The effect of Satisfaction, Switching Costs, and Interpersonal Bonds on Service Loyalty”, Doctor of Philosophy Dissertation, Arizona State University, USA.

Grewal, D., Baker, J., Levy, M., \& Voss, G. B. (2003). The Effects of Wait Expectations and Store Atmosphere Evaluations on Patronage Intentions in Service-Intensive Retail Stores.Journal of Retailing, 79(4), 259-268.

Grewal, D., Gotlieb, J., \& Marmorstein, H. (2000). The moderating effect of the service context on the relationship between price and post-consumption perceptions of service quality. Journal of Business and Psychology, 14(4), 579-591.

Gronroos, C. (2007). Service Management and Marketing: Customer Management in Service Competition, 3rd ed., John Wiley and Sons Ltd, Chichester.

Grubb., Edward L., \& Grathwohl, Harrison L. (1967). Consumer self-concept, symbolism and market behavior: a theoretical approach. Journal of Marketing, 31, 22-27.

Gummesson, E. (1978). Toward a theory of professional service marketing, Industrial Marketing Management, 7(2), 89-95. 


\section{$\Lambda$ Macrothink}

Journal of Entrepreneurship and Business Innovation ISSN 2332-8851

Gursoy, D., Chen, M. H., \& Kim, H. J. (2005). The US airlines relative positioning based on attributes of service quality. Tourism Management, 26(1), 57-67.

Gutman, J. (1982). A means-end chain model based on consumers' categorization process. Journal of Marketing, 46(spring), 60-72.

Gutmann, Matthew. (1997). Trafficking in men: the anthropology of masculinity. Annual Review of Anthropology, 26, 385-409.

Hackl, P., Scharitzer, D., \& Zuba, R., (1996). The Austrian Customer Satisfaction Barometer (ACSB): A pilot study. Der Markt 35, 86-94.

Hallowell, R. (1996). The relationships of customer satisfaction, customer sense of fulfillment and profitability: an empirical study. International Journal of Service Industry Management, 7(4), 27-42.

Hamilton, R. T. (2007). Small business growth: recent evidence and new directions. International journal of entre perceivedneurial Behaviour and Research, 13(5), 296-296.

Haque, A. K. M., Sarwar, A. A. M., Yasmin, F., Anwar, A., \& Nuruzzaman (2012). The impact of customer perceived service quality on customer satisfaction for private health centre in Malaysia: a structural equation modeling approach. Information Management and Business Review, 4(5), 257-267.

Harris, Lloyd C., \& Goode, Mark M.H. (2004). The four levels of loyalty and the pivotal role of trust: a study of online service dynamics. Journal of Retailing, 80(2), 139-158.

Hartman, K.B., \& Spiro, R.L., (2005). Recapturing store image in customer-based store equity: a construct conceptualization. Journal of Business Research,58(8), 1112-1120.

Hawkins, D.J., Best, R.J., \& Coney, K.A. (2002).Consumer BehaviourBuilding Marketing Strategy, 9th ed., McGraw-Hill, New Delhi, 437-47.

Hirschman, A.O, (1970). Exit, Voice, and Loyalty: Responses to Decline in Firms, Organizations, and States.Cambridge, MA: Harvard University Perceivedss.

Hoffman, K.D., \& Bateson, J.E.G. (2002).Essentials of Service Marketing: Concepts, Strategies and Cases (2nd ed.). Fort Worth, Texas: Harcourt College Publishers, 324.

Hofstede, G, (1984). Culture's Consequences: International Differences in Work-Related Values. Beverly Hills, Sage Publication.

Holbrook, M.B. (1994). The nature of customer value: An axiology of service in the consumption experience, in Service Quality: New Directions in Theory and Practice, R.T. Rust and R.Oliver, eds.London: Sage Publication.

Holjevac, I.A., Markovic, S., \&Raspor, S. (2013). Customer satisfaction measurement in hotel industry: Content analysis study. March, 14, 2013 from Retrieved From: http://bib.irb.hr/datoteka/397335.PAP039.pdf.

Holton, E. H., \& Burnett, M. B. (1997).Qualitative research methods.In R. A.Swanson, and E. 
F. Holton (Eds.), Human resource development research handbook: Linking research and practice. San Francisco:Berrett-Koehler Publishers.

Hoots, M. (2005). Customer relationship management for facility managers.Journal of Facilities Management, 3(4).

Hossain, M., \& Leo, S. (2009). Customer perception on service quality in retail banking in Middle East: the case of Qatar. International Journal of Islamic and Middle Eastern Finance and Management, 2(4), 338-350.

Howat, G., Crilley, G., \& McGrath, R. (2008). A focused service quality, benefits, overall satisfaction and loyalty model for public aquatic centres. Managing Leisure, 13,139-161.

Hsu, S.-H., Chen, W.-H., \& Hsueh, J.-T.(2006). Application of Customer Satisfaction Study to Derive Customer Knowledge. Total Quality Management, 17(4), 439-454.

Huang, C.-H. (2014). Reconsidering the measurement of service quality in hotel sector: A dyad study. International Journal of Modern Business Issues of Global Market, 2(1), 32-44.

Huber, F., Herrmann, A., \& Morgan, R. E. (2001). Gaining competitive advantage through customer value oriented management. Journal of Consumer Marketing, 18(1), 41-53.

Hully SB., Cummings SR., Browner WS., Grady D., Hearst N., \& Newman TB. (2001). Designing clinical research. 2nd ed. Philadelphia: Lippincott, Willians, and Wilkins.

Hutchinson, J., Lai, F., \& Wang, Y. (2009).Understanding the relationships of quality, value, equity, satisfaction, and behavioral intentions among golf travelers. Tourism Management, 30(2), 298-308.

Igbaria, M., Iivari, J., \& Maragahh, H. (1995). Why do individuals use computer technology? A Finnish case study.Information and Management, 29(5), 227-238.Image of the store-loyal customer, Journal of Retailing, 50, 73-84.

Images retail report (2012) Saudi grocery market set for growth. imagesretailme.com

Imrie, Brian C.; Cadogan, John W., \& McNaughton, Rod. (2002). The service quality construct on a global stage. Managing Service Quality, 12(1), 10-18.In: Journal of Business \& Industrial Marketing 24(1): 3-13. In: Journal of Consumer Marketing 26(6): 392-402.

Ismail, A., Abdullah, M. M., \& Francis, S. K. (2009).Exploring The Relationships among Service Quality Features, Perceived Value and Customer Satisfaction.Journal of Industrial Engineering and Management, 2(1), 230-250.

Jacoby, Jacob.,\& Chestnut, Robert W. (1978). Brand Loyalty. New York: John Wiley and Sons.

Jajaee, S. M., \& Ahmad, F. B. S. (2012). Evaluating the Relationship between Service Quality and Customer Satisfaction in the Australian Car Insurance Industry. International Conference on Economics, Business Innovation, 38, 219-223.

Jamal, A., \& Naser, K. (2002). Customer satisfaction and retail banking: An assessment of 
some of the key antecedents of customer satisfaction in retail banking. International Journal of Bank Marketing, 20(4), 146-160.

Jamali, D. (2007). A study of customer satisfaction in the context of a public private partnership.International Journal of Quality \& Reliability Management, 24(4): 370-385.

Johnson M.D., Herrmann A., \& Huber F. (2006).The Evolution of Loyalty Intentions. American Marketing Association, 70, 122-132.

Juggessur, J. (2009). Luxury Designer Handbag or Counterfeit?An Investigation into the Antecedents Influencing Women's Purchasing Behaviour of Luxury Designer and Counterfeit Brands.Brunel Business School, Brunel University.

Juran, J.M. (1980).Quality Planning and Analysis, McGraw- Hill, New York, NY.

Kahn, Barbara E., Kalwani, Manohar U., \& Morrison, Donald G. (1986).Measuring Variety Seeking and Reinforcement Behaviors Using Panel Data.Journal of Marketing Research, 23(May), 89-100.

Kandampully, J., \& Suhartanto, D. (2000). Customer sense of fulfillment in the hotel industry: the role of customer satisfaction and image. International Journal of Contemporary Hospitality Management, 12(6), 346-351.

Karlsson, J. (2012). Possibilities of Using Thermal Mass in Buildings to Save Energy Cut Power Consumption Peaks and Increase the Thermal Comfort. Lund Institute Of Technology Lund University.

Karna, S. (2004).Analysing customer satisfaction and quality in construction: the case of public and private customers, Nordic Journal of Surveying and Real Estate Research, Special Series, 2, 66-80.

Karunanayake, A. (2011). Impact of Switching Cost on Customer Satisfaction and Customer Retention for Internet Banking. A Study Based On Sri Lankan Commercial Banks, 10(2009), 4-6.

Kasper, H., van Helsdingen, P., \& Gabbott, M. (2006). Service Marketing Management: A Strategic Perspective, Chichester: John Wiley.

Kassim, N., \& Abdullah, N. A. (2010). The effect of perceived service quality dimensions on customer satisfaction, trust, and loyalty in e-commerce settings: A cross cultural analysis. Asia Pacific Journal of Marketing and Logistics, 22(3), 351-371.

Kayaman R.,\& Arasli H. (2007). Customer based brand equity: evidence from the hotel industry. Managing Service Quality, 17(1), 92-109.

Kazi Omar Siddiqi ( 2011), Interrelations between Service Quality Attributes, Customer Satisfaction and Customer Loyalty in the Retail Banking Sector in Bangladesh, International Journal of Business and Management Vol. 6, No. 3.

Kelly, J. (2004). Social partnership agreements in Britain: Labor cooperation and compliance. 
Industrial Relations, 43(1), 267-292.

Kelly, S., \& Breslin, J. (2010). Women's Rights in the Middle East and North Africa: Progress amid Resistance. New York, NY: Freedom House; Lanham, MD: Rowman and Littlefi eld.

Khare, A. (2013). Culture, small retail stores, and Indian consumer perceivedferences: a moderating role of Demographics. The International Review of Retail, Distribution and Consumer Research,23(1), 87-109.

Kim, S. H. (2011). Antecedents of Destination Loyalty. University of Florida, . Retrieved March, 1, 2011 from:

Http://Ufdcimages.Uflib.Ufl.Edu/Uf/E0/04/15/12/00001/Kim_S.Pdf, 10-41.

Kim, S., \& Jin, B. (2002).Validating the retail service quality scale for US and Korean customers of discount stores: an exploratory study.Journal of Service Marketing, 16 (3), 223-37.

Kim, Y., Kim, Y., \& Lee, Y. (2011).Perceived service quality for South Korean domestic airlines. Total Quality Management and Business Excellence, 22(10), 1041-1056.

Kim, Y.-K., Sullivan, P., \& Cardona Forney, J. (2007).Experiential retailing: Concepts and strategies that sell. New York: Fairchild Publications, Inc

Kim, Y-K., Lee, M., \& Park, S. (2012). Shopping value orientation: Conceptualization and measurement. Journal of Business Research, in press.

Kimani, S.W., Kagira, E.K., Kendi, L., Wawire, C.M., \& Fourier, U.J. (2012).Shoppers perception of retail service quality: supermarkets versus small convenience shops (Dukas) in Kenya. Journal of Management \& Strategy, 3(1), 55-66.

Kline, R. B. (2005). Principles and Practice of Structural Equation Modeling (2nd Ed.). New York: Guilford Press.

Kopp, R. J., Eng, R. J., \& Tigert, D. J. (1989).A competitive structure and segmentation analysis of the Chicago Fashion Market.Journal of Retailing, 65(Winter), 496-515.

Kotler, P. (2000). Marketing Management, Millenium Edition.Upper Saddle River, New Jersey, 21-18.

Kotler, P., \& Armstrong, G. (2010).Principles of Marketing. 13th ed. London: Pearson.

Kotler, P., \& Keller, K. (2006).Marketing Management.12th Edition.Upper saddle River, NJ.Pearson.Perceivedntice Hall.

Kotler, P., \&Keller, K. (2009).Creating Customer Value, Satisfaction, and Loyalty. Published by Perceivedntice Hall, . Retrieved April, 15, 2009 from http://wps.pearsoncustom.com/wps/media/objects/2426/2484677/MKT10_Ch04.pd

Krejcie, R. V., \& Morgan, D. W. (1970). Determining sample size for research activities. Educational and Psychological Measurement, 30, 607-610. 
Kumar, M., Kee, F. T., \& Charles, V. (2010). Comparative evaluation of critical factors in delivering service quality of banks: An application of dominance analysis in modified SERVQUAL model. International Journal of Quality and Reliability Management, 27(3), 351-377.

Kumar, Piyush (2005). The competitive impact of service process improvement: examining customers' waiting experiences in retail markets. Journal of Retailing, 81 (3), 171-180.

Kumar, S.A., Mani, B.T., Mahalingam, S., \& Vanjikovan, M. (2010). Influence of service quality on attitudinal loyalty in private retail banking: an empirical study. The IUP Journal of Management Research, 9(4), 21-38.

Kumar, V., Batista, L., \& Roger, M. (2011).The Impact of Operations Performance on Customer sense of fulfillment. The Impact of Operations Performance on Customer sense of fulfillment, 3(2), 158-171.

Lagrosen, (2004).Examination of the Dimensions of Quality in Higher Education.Quality Assurance in Education, 12(2), 61-69.

Lamb, C.W, Hair, J. F., \& McDaniel, C. (2006).Principles of Marketing.Thomson South-Western.

Laroche, M., Ueltschy, L. C., Abe, S., Cleveland, M., \& Yannopoulos, P. (2004). Service Quality Perceptions and Customer Satisfaction: Evaluating the Role of Culture, Journal of International Marketing, 12(3), 58-85.

Lewis, Robert C., \& Bernard H. Booms (1983).The Marketing Aspects of Service Quality, In Emerging Perspectives on Services Marketing, L Berry, G.Shostak, and G.Upah, Eds., Chicago: American Marketing Association, 99-107.

Liao, J., \& Wang, L. (2009). Face as a Mediator of the relationship between material value and brand consciousness. Psychology and Marketing, 26, 987-1001.

Lindquist, M. (2006). For better business results, focus on your customer, not your competition, Cost engineering, 8(3), 10

Liu, C. T., Guo., Y. M., \& Hsieh, T. Y. (2010). Measuring user perceived service quality of online auction sites. The Service Industries Journal, 30(7), 1177-1197.

Luo, X. \& Homburg, C. (2007).Neglected Outcomes of Customer Satisfaction.Journal of Marketing, 71(2), 133-149.

Ma, Y.J.,\& Niehm, L.S. (2006), "Service expectations of older generation Y customers An examination of apparel retail settings", Emerald Group Publishing Limited, Managing Service Quality, 16(6), 620-640.

Machleit, K. A., Eroglu, S. A., \& Mantel, S. P. (2000). Perceived retail crowding and shopping satisfaction: What modifies this relationship? Journal of Consumer Psychology, 9(1), 29-42. 
Macintosh, G., \& Lockshin, L. (1997). Retail relationships and store loyalty: a multi- level perspective.International Journal of Research in Marketing. 14(5), 487-497.

Magi \& Julander, 2009; Yeung et al., 2002; Luo and Homburg, 2007

Malhotra, Naresh K., Ulgado, Francis M., Agarwal, James.,\& Baalbaki, Imad B. (1994). International Services Marketing: A Comparative Evaluation of the Dimensions of Service Quality between Developed and Developing Countries. International Marketing Review, 11(2), 5-15.

Malik, F. (2012). The Impact of Price Perception, Service Quality, and Brand Image on Customer sense of fulfillment (Study of Hospitality Industry in Pakistan). Interdisciplinary Journal of Contemporary Research in Business, 4.

Malik, M.E., Naeem, B., \& Arif, Z. (2011). How Do Service Quality Perceptions Contribute in Satisfying Banking Customers? International Journal of Contemporary Research in Business, 3(8), 646-653.

Mandhachitara, R. \& Poolthong, Y. (2011) A model of customer sense of fulfillment and corporate social responsibility, Journal of Services Marketing, 25(2): 122-133.

Manu, M. (2011).Quality and Customer Satisfaction Perspective in Organisations by Gap and Total Quality Improvement Methods. Universitas Wasaensis, Retrieved March, 10, 2011 from: Http://Www.Uva.Fi/Materiaali/Pdf/Isbn_978-952-476-337-0.Pdf

Manyiwa, S., \& Crawford, I (2001).Determining linkages between consumer choices in a social context and the consumers' values: A means-end approach. Journal of Consumer Behavior, 2(1), 54-70.

Mason, N. (1996). Store Loyalty - That Old Chestnut, Nielsen Research, Oxford, 6-15.

Mattila, A.S., \& Patterson, P.G. (2004).The impact of culture on consumers' perceptions of service recovery efforts.Journal of Retailing, 80 (3), 196-206.

McDougall, P. P., \& Oviatt, B. M. (2000). International entreperceivedneurship: the intersection of two research paths. The Academy of Management Journal, 43(5), 902-906.

McGoldrick, P.J., \& Andre, E. (1997). Consumer misbehaviour: promiscuity or loyalty in grocery shopping. Journal of Retailing and Consumer Services, 4(2), 73-81.

McKenzie, B. (2006). Retail service quality success factors in Estonia: a qualitative approach, Baltic Journal of Management, 1(3), 352-369.

Medina, S., \& Ward, R.W. (1999).A model of retail outlet selection for beef.International Food and Agribusiness Management Review, 2(2), 195-219.

Melville, Ian (1999). Marketing in Japan.Oxford, UK: Butterworth- Heinemann.

Mendenhall, W., Reinmuth, J. E., \& Beaver, R. J. (1993).Statistics for management and 
economics.California: Duxbury Perceivedss.

Merrilees, B., \& Miller, D. (2001). Superstore interactivity: a new self-service paradigm of retail service? International Journal of Retail \& Distribution Management, 29 (8/9), 379-389.

Meyers, L. S., Gamst, G., \& Guarino, A. J. (2006).Applied Multivariate Research. California: Sage Publications Inc.

Min-Hsin, H. (2009).Using service quality to enhance the perception about quality of store brands. Total Quality Management and Business Excellence, 20(2), 241-252.

Mittal, B., \& Lassar, W. M. (1996). The role of personalization in service encounters. Journal of Retailing, 72(spring), 95-109.

Mittal, V., \& Kamakura, W.A. (2001). Satisfaction, repurchase intent, and repurchase behaviour: investigating the moderating effect of customer characteristic, Journal of Marketing Research, 38(1), 131-142.

Mohammad., Tabriz., Chalous., \& Aras. (2013). The effect of customer satisfaction on word of mouth communication. Research Journal of Applied Sciences, Engineering and Technology, 5(8), 2569-2575.

Monroe, K.B. (2003). Pricing: Making Profitable Decisions, 3rd ed., McGraw-Hill/Irwin, Burr Ridge, IL.

Morgan, R., \& Hunt, Shelby.D. (1994).The commitment-trust theory of relationship marketing. Journal of Marketing, 58(3), 20-38.

Morganosky, M.A. (1995). Consumer patronage of manufacturers' outlets.Clothing and Textiles Research Journal, 13(4), 273-9.

Mosahab, R., Mahamad, O., \& Ramayah, T. (2010). Service quality, customer satisfaction and loyalty: a test of mediation. International Business Research, 3(4), 72.

Mousa, H. (2012). Global Agricultural Information Network.In SA1217 (Ed.), Exporter Guide.Riyadh public distribution.

Mustafa. (2011). Determinants of e-commerce customer satisfaction, trust, and loyalty in saudi arabia. Journal of Electronic Commerce Research, 12(1), 78-89.

Muyeed, A. (2012). Customer perception on service quality in retail banking in developing countries: A case study', International Journal of Marketing Studies, 4(1), 116-122.

Mzukisi Qobo.,\& Mills Soko. (2010). Saudi Arabia as an Emerging Market: Commercial Opportunitiesand Challenges for South Africa. South African Institute of International Affairs, 69(October), 5-12.

Naeem, H., \& Saif, I. (2009). Service Quality and its impact on Customer Satisfaction: empirical evidence from the Pakistani banking sector. The International Business and Economics Research Journal, 8(12), 99. 


\section{Macrothink}

Journal of Entrepreneurship and Business Innovation ISSN 2332-8851 2014, Vol. 1, No. 1

Narsky, I (2003).Estimation of Goodness-of-Fit in Multidimensional Analysis Using Distance to Nearest Neighbor", Physics, 0306171.

Ndubisi, N.O., Malhotra, N.K. \& Chan, K.W. (2009). Relationship marketing, customer satisfaction and loyalty: a theoretical and empirical analysis from an Asian perspective, Journal of International Consumer Marketing, 21(1), 5.

Neuman, W. L. (1997). Social research methods.Qualitative and quantitative approaches (3rd Ed.). MA: Allyn and Bacon.

Nijmeijer, M., Worsley, A., \& Astil, B. (2004).An exploration of the relations between food lifestyles and vegetable consumption.British Food Journal, 106(7), 520-533.

Noble, Stephanie M., David A. Griffith., \& Mavis T. Adjei (2006). Drivers of local merchant loyalty: understanding the influence of gender and shopping motives. Journal of Retailing, 82(3), 177-188.

Nunnally, J.C. (1978). Pyschometric Theory, 2nd ed., McGraw-Hill, New York, NY.

Ofir, C., \& Simonson, I. (2001). In search of negative customer feedback: the effect of expecting to evaluate on satisfaction evaluations. Journal of Marketing Research, 38(2), 170-182.

Olajide, O. P. (2011). causal direction between customer satisfaction and service quality: a review of literature. European Journal of Humanities and Social Sciences, 2(1), 87-93.

Oliver, R. L. (1999). Whence consumer loyalty? Journal of Marketing, 63(Special Issue), 33-44.

Oliver. R. L. (1997). Satisfaction: A behavioral perspective on the customer. New York, NY: Irwin/McGraw-Hill.

Olorunniwo, F., Hsu, M.K., \& Udo, G.J. (2006).Service quality, customer satisfaction and behavioural intentions in the service factory.Journal of Services Marketing, 20(1), 59-72.

Olsen, S. (2007). Repurchase loyalty: The role of involvement and satisfaction. Psychology and Marketing, 24(4), 315-341.

Olshavsky, R. W., \& Miller, J. A. (1972).Consumer Expectations, Product Performance and Perceived Product Quality.Journal of Marketing Research, 9, 19-21.

Othaim, A. (2012). Al Othaim Hypermarket. Al Riyadh News Paper (15859).

Otieno.R., Harrow, C. \& Lea-Greenwood, G. (2005). The unhappy shopper, a retail experience: exploring fashion, fit and affordability. International Journal of Retail \& Distribution Management, 33(4), 298-309.

Ouroussoff, N. (2010). Saudi Urban Projects Are a Window to Modernity. Critic's Notebook, The New York Times. Retrieved January, 7, 2010 from www.nytimes.com/2010/12/13/arts/design/13desert.html?pagewanted=alland_r=0 


\section{I Macrothink}

Journal of Entrepreneurship and Business Innovation ISSN 2332-8851

Outi, U. (2001). Consumer perceptions of grocery retail formats and brands. International Journal of Retail and Distribution Management, 29(5), 214-25.

Owolabi (2001).Quality Control in the Service Sector in Nigeria.An unpublished MBAP. Praba Devi and R. Sellappan (2009) Service Quality at Retail Stores - Customers' Perception, JK Journal of Management \& Technology, 1(1), 41-52.

Pandey, A.C., \& Darla, S. (2012). A Study on the Influence of Store Level Services on Store Loyalty of Shoppers in Organized Retail Stores.International Journal of Management ResearchAnd Review,2(4), 600-622.

Pandey, A.C., \& Kumar, P. (2013).Impact of Lifestyle on Brand Perceivedference of Buyer Behaviour.International Monthly Refereed Journal of Research in Management \& Technology, 11(August), 151-163.

Parasuraman, A., \& Grewal, D. (2000). The impact of technology on the quality-value-loyalty chain: A research agenda. Journal of the Academy of Marketing Science.18 (1), 168-174.

Parasuraman, A., Berry, L., \& Zeithaml, V.A. (1991).Understanding customer expectations of service. Sloan Management Review, 32(3), 39-49.

Parasuraman, A., Zeithaml, V. A., \& Berry, L. L. (1988).A multiple-item scale for measuring consumer perceptions of service quality. Journal of Retailing, 64 (1), 12-40.

Parasuraman, A., Zeithaml, V. A., \& Berry, L. L. (1994). Alternative scales for measuring service quality: a comparative assessment based on psychometric and diagnostic criteria. Journal of Retailing, 70(3), 201-230.

Patterson P.G.,\& Spreng R.A. (1997). Modelling the relationship between perceived value, satisfaction and repurchase intentions in a business-to-business, services context: an empirical examination.International Journal of Service Industry Management, 8(5), 414-434.

Paul., Hennig-Thurau., Gremler., Gwinner., \& Wiertz, (2008). Toward a Theory of Repeat Purchase Drivers for Consumer Services.Original Empirical Research, 1(September), 1-23.

Peter J. P.,\& Olson J.C. (1990). Consumer Behaviour and Marketing Strategy, 2nd edition, Illinois.

Plooy, A.T.D., Jager, J.W.D., \& D. Zyl, V. (2012).Drivers of perceived service quality in selected informal grocery retail stores in Gauteng, South Africa', Southern African Business Review, 16(1), 94-121.

Pont, M. and McQuilken, L.(2004):“An empirical investigation of customer satisfaction and loyalty across two divergent bank segments", Journal of Financial Services Marketing, Jun 2005; 9,4, pp. 344-359

Poujol, J. F., Siadou-Martin, B., Vidal, D., \& Pellat, G. (2012). Examining The Impact of Salespeople's Relational Behaviors and Organizational Fairness on Customer sense of 
fulfillment The $12^{\text {th }}$. International Research Conference in Service Management, 29/30/31(1), 2-10.

Prabhakar, G. V., \& Ram, P. (2013). SERVQUAL and customer satisfaction: the mediating influence of communication in the privatized telecom sector. International Journal of Academic Research in Business and Social Sciences, 3(3), 135-148.

Prasad, C.J., \& Aryasri, A. R. (2011). Effect of shopper attributes on retail format choice behaviour for food and grocery retailing in India. International Journal of Retail and Distribution Management. 39(1), 68-86.

Purgailis.,\& Zaksa, P. (2012).The Student Loyalty as a Part of Higher Education. Organization's Intellectual Capital.

R. A. Schmidt.,\& E. A. Pioch (2005). Community pharmacies under perceivedssure - can brand help? International Journal of Retail \& Distribution Management,33(7), 494-504.

Ragavan.,\& Mageh (2013). A Study on Service Quality Perspectives and Customer Satisfaction in New Private Sector Banks.IOSR. Journal of Business and Management (IOSR-JBM), 7(2), 26-33.

Rahman, M. S. (2012). Service quality, corporate image and customer's satisfaction towards customers perception: an exploratory study on telecom customersin bangladesh. Business Intelligence Journal, 5(1).

Rajamohan, P.G. (2012). Consumer behaviour and lifestyle marketing urban,.International Journal of Marketing, Financial Services and Management Research, 1(10), 152.

Raven, P.V., \& Welsh, D.H.B. (2004). An exploratory study of influences on retail service quality: A focus on Kuwait and Lebanon. The Journal of Service Marketing, 18(3), 198-214.

Raza, M. A., Siddiquei, A. N., Awan, H. M., \& Bukhari, K. (2012).Relationship between service quality, perceived value, satisfaction and revisit intention in hotel industry. Journal of Contemporary Research in Business, 4(8), 788-805.

Reichheld, F.F. and Sasser, W.E. Jr. (1990). Zero Defections: Quality Comes to Service. Harvard Business Review, September-October, pp. 105-11.

Reichheld, F.F., \& Teal, T. (1996).The Loyalty Effect, Harvard Business, School Perceivedss, Boston, MA.Research. 13, 121-127.

Reynolds, F. D, Darden, W. R., \& Martin, W. S. (1974-1975). Developing an image of the store-loyal customer, Journal of Retailing, 50, 73-84.

Reynolds, Kristy E., \& Arnold, Mark J. (2000). Customer sense of fulfillment to the salesperson and the store: examining relationship customers in an upscale retail context. Journal of Personal Selling and Sales Management, 15(2), 89-98.

Reynolds, T.J., \& Gutman, J. (1988).Laddering theory, method, analysis, and interperceivedtation.Journal of Advertising Research, 28(1), 11-31. 
RNCOS Industry Research Solutions (2008).Booming Retail Sector in UAE, . Retrieved Feb, 15, 2013 from:http://www.rncos.com/Report/IM108.htm,).

Roberts Lombard. (2009). Customer relationships in the retail travel trade, what is the opinion of management? Journal of Contemporary Management, 6, 409 - 429.

Roberts, K., S. Varki., \& R. Brodie (2003).measuring the quality of relationships in consumer services: an empirical study. European Journal of Marketing, 37(1/2), 169- 196.

Robinson, D. (2011). Customer sense of fulfillment Programs: Best Practices. Haas School of Business, University of California, Berkeley, Retrieved from:

Rust., Zahorik., \& Keiningham, T. L. (1996). Service Marketing.New York, NY: Harper Collins.

Ruvio, A., \& Shoham, A. (2007).innovativeness, exploratory behavior, market mavenship, and opinion leadership: an empirical examination in the asian context. Psychology and Marketing, 24(8), 703-722.

Rym, B., Olfa, B., \& Capatina, B. A. (2013). Retail logistics service quality: a cross- cultural surveyon customer perceptions, International Journal of Retail and Distribution Management, $41(8), 627-647$.

Sampson, S., \& Tigert, D. (1992).The impact of warehouse membership clubs: the wheel

Sasikala. (2013). Impact of demographics on service quality, customer satisfaction and loyalty in the indian banking in vellore district. Asia Pacific Journal of Marketing and Management Review,2(6), 102-112.

Saudi Standard, Metrology and Quality Organization (2012).Available at: http://www.saso.gov.sa/en/pages/default.aspx.

Schwartz, S.H., (1997).Values and culture. In: Munro, D. (Ed.), Motivation and Culture. Routledge, New York, 69-84.

Sekaran, U. (2005). Research methods for business.A skill building approach (4th Ed.). NY: John Wiley and Sons Inc.

Sengupta, A., (2008). Emergence of modern Indian retail: an historical perspective, International Journal of Retail \& Distribution Management, 36(9), 689 - 700

Shamdasani, A. Mukherjee., \& N. Malhotra, (2008).Antecedents and consequences of service quality in consumer evaluation of self-service internet technologies.The Service Industries Journal, 28(1), 117-38.

Sheth, J.N. (1983).An integrative theory of patronage perceivedference and behavior. In Darden, W.R. and Lusch, R.F. (Eds), Patronage Behaviour and Retail Management, North Holland, New York, NY, 9-28.

Shim, S., \& Bickle, M.C. (1994). Benefit segments of the female apparel market: psychographics, shopping orientations, and demographics. Clothing and Textiles Research 
Journal, 12(2), 1-12.

Shim, S., \& Kotsiopoulos, A. (1993). A typology of apparel shopping orientation segments among female consumers. Clothing and Textiles Research Journal, 12(1), 73-85.

Shim.,\& Eastlick, (1998). The hierarchical influence of personal values on mall shopping attitude and behavior, Journal of Retailing, 74(1), 139-160.

Shostack, G. L. (1987). Service positioning through structural change, Journal of Marketing, $51,34-43$.

Shpetim Cerri. (2012). Exploring Factor Affecting Trust And Relationship Quality In a Supply Chain Context. Journal of Business Studies Quarterly, 4(1/4), 16-35.

Simonson, Itamar. (1999). The effect of product assortment on buyer perceivedferences. Journal of Retailing, 75(3), 347-370.

Singh, B.J., \& Khanduja, D. (2010).Customer requirements grouping a perceivedrequisite for successful implementation of TQM in technical education. International Journal of Management in Education, 4(2), 201-215.

Sinha, P. K., Mathew, E., \& Kansal, A. (2005). Socio-Economic and Demographic Importance of Store Attributes, Store Format Choice Behavior.

Sinha, P.K. (2003). Shopping orientation in the evolving Indian market.Vikalpa, 28(2), 13-22.

Sinha, P.K., \& Banerjee, A. (2004).Sore choice in an evolving market, International Journal of Retail and Distribution Management, 32 (10).

Sinha, P.K., \& Uniyal, D.P. (2005).Using observational research for behavioural segmentation of shoppers. Journal of Retailing and Consumer Services, 6(5), 161-173.

Sirgy, M. Joseph., \& A. Coskun Samli (1985). A path analytic model of store loyalty involvoing self concept, store image, geographic loyalty and socioeconomic status. Journal of the Academy of Marketing Science, 13(3), 265-291.

Siu, N.Y-M., \& J. C-W.Mou (2005).Measuring service quality in internet banking: the case of Hong Kong, Journal of International Consumer Marketing, 17(4), 97-114.

Sivadas, E. and Baker-Prewitt, J.L. (2000).An Examination of the Relationship between Service Quality, Customer Satisfaction and Store Loyalty.International Journal of Retail and Distribution Management. 28(2/3) Pp. 73-82.

Slama, M.E., \& A. Tashlian (1985). Selected socioeconomic and demographic characteristics associated with purchasing involvement. Journal of Marketing, 1, 72-82.

Sobel, M. E. (1982). Asymptotic confidence intervals for indirect effects in structural equations models.In S. Leinhart (Ed.), Sociological Methodology (pp. 290-312). San Francisco: Jossey-Bass.

Soderlund, M. (1998). Customer satisfaction and its consequences on customer behaviour 
revisited: The impact of different levels of satisfaction on word-of-mouth, feedback to the supplier and loyalty. International Journal of Service Industry Management, 9(2), 169-188.

South, Scott J., \& Spitze, Glenna (1994).Housework in marital and non-marital households.American Sociological Review, 59 (June), 327-347.

Srinivasan, Anderson.,\& Kishore Ponnavolu, (2002). Customer sense of fulfillment in e-commerce: an exploration of its antecedents and consequences. Journal of Retailing 78, $41-50$.

Stone, B. (1995). Successful direct marketing methods. Lincolnwood, IL: NTC Business Books, 37-57.

Storbacka, K. and Lehtinen, J. (2001).Customer Relationship Management.Creating Competitive Advantage through Win-Win Relationship Strategy. Mc Graw-Hill.

Sweeney, J. C., Soutar, G. N., \& Johnson, L. W. (1999). The role of perceived risk in the quality-value relationship: a study in a retail environment. Journal of Retailing, 75(1), 77-105.

Swinyard, W. R., \& Scott M. (2011).Activities, interests, and opinions of online shoppers and non-shoppers.International Business \& Economics Research Journal, 3(4), 37-46.

Swinyard, W.R. (1998). Shopping mall customer values: the national mall shopper and the list of values, Journal of Retailing and Consumer Services, 5(3), 167-172.

Szymanski, D., \& Henard, D. (2001). Customer satisfaction: A meta-analysis of the empirical evidence. Journal of the Academy of Marketing Science, 29(1), 16-35.

Tabachnick, B. G., \& Fidell, L.S. (2007).Using multivariate statistics (5th Ed.).Boston: Pearson Education Inc.

Tam, J. M. (2012). Linking perceived service quality to relational outcomes in a Chinese context. Journal of International Consumer Marketing, 24(1-2), 7-23.

Tauber, E.M., (1972). Why do people shop? Journal of Marketing, 36 (4), 46-49.

Taylor S.A.,\& Baker TL. (1994). An assessment of the relationship between service quality and customer satisfaction in the formation of consumers' purchase intentions. Journal of Retailing,70(2), $163-78$.

Taylor, S. A., \& Cronin, J. J. (1994).Modelling patient satisfaction and service quality.Journal of Health Care Marketing, 14(1), 34-44.

Teas, R.K. (1993).Expectations, performance evaluation, and consumers' perceptions of quality. Journal of Marketing, 57(October), 18-34.

Tellis, Gerard J. (1988). Advertising exposure, loyalty, and brand purchase: a two-stage model of choice. Journal of Marketing Research, 25(May), 204-212.

Terblanche, N.S., \& Boshoff, C. (2004). The in-store shopping experience: a comparative study of supermarket and clothing store customers. South African Journal of Business 
Management, 35(4), 1-10.

Ting, L. W. (2009). The Impact of Store Attributes on Consumer Shopping Behaviour: A Study of Grocery Stores. Bachelor of Business (Marketing), Monash University, Australia, $\quad$ Retrieved July, $\quad 15, \quad 2009$ from http://dspace.fsktm.um.edu.my/bitstream/1812/538/1/WT\%20Thesis\%20 Perceivedface.pdf.

Tor Wallin Andreassen Bodil Lindestad, (1998),"Customer loyalty and complex services", International Journal of Service Industry Management, Vol. 9 Iss 1 pp. 7 - 23

Trasorras, R., Weinstein, A., \& Abratt, R. (2009).Value, satisfaction, loyalty and retention in professional services.Marketing Intelligence and Planning, 27(5), 615-632.

Tse, D. K., \& Wilton, P. C. (1988). Models of consumer satisfaction formation: An extension. Journal of Marketing Research, 25, 204-212.

Tsoukatos, E., \& Mastrojiannie, E. (2010): Key Determinants of Service Quality in Retail Banking. EuroMed Journal of Business, 5(1), 85-100.

Tuan, D. N. M. (2012). 132Effects of Service Quality and Price Fairness on Student Satisfaction.International Journal of Business and Social Science, 3(19).

Tuncalp, S., (1988). Marketing education in developing countries: The view from Saudi Arabia. Journal of Marketing Education (fall), 54-61.

Underwood, Robert L. (2003). The communicative power of product packaging: Creating brand identity via lived and mediated experience. Journal of Marketing Theory and Practice, $11(1), 62-76$.

Urban, W. (2010).Customers'experiences as a Factor Affecting Perceived Service Quality.Economics and Management, 820-826.

Van der Haar J.W., Kemp R., \& Omta O. (2001).Creating value that cannot be copied. Industrial Marketing Management, 30, 627-636.

Vazquez-Carrasco, R., \& Foxall, G.R. (2006). Positive vs. negative switching barriers: the influence of service consumers' need for variety, Journal of Consumer Behaviour, 2, 367-379.

Veloutsou, C, Daskou, S. and Daskou, A. (2004):“Are the determinants of bank loyalty brand specific?” Journal of Financial Services Marketing, Vol.9, 2, pp.113-12.

Venkatrama, N. M., \& Nelson, T. (2008). From servicescape to consumptionscape: A Photo-elicitation study of starbukks in the new China, Journal of International Business Studies, advance online publication,10.1057/ palgrave. Jibs, 8400353.

Vesel, P., \& Zabkar, V. (2009).Managing customer sense of fulfillment through the mediating role of satisfaction in the DIY retail loyalty program. Journal of Retailing and Consumer Services, 16(5), 396-406. 


\section{Ml Macrothink}

Journal of Entrepreneurship and Business Innovation ISSN 2332-8851 2014, Vol. 1, No. 1

Vidich, A. J. (2009). With a Critical Eye. The University of Tennessee Libraries, Knoxville, Retrieved March, 15, 2009 from Http://Www.Bpatc.Org.Bd/Elibrary/Files/1271324388withacriticaleye.Pdf.

Voss., Roth., Rosenzweig., Blackmon., \& Andchase, (2004). A tale of two countries' conservatism, service quality, and feedback on customer satisfaction.Journal of Service Research, 6(3), 212-230

Wallace, David W., Giese, Joan L., \& Johnson, Jean L. (2004).Customer retailer loyalty in the context of multiple channel strategies.Journal of Retailing, 80(4), 249-263.

Weiner, B. (1986). An attribution theory of motivation and emotion. New York, NY: Springer-Veriag.

Weitz, B. A., \& Whitfield, M. B. (2006).Trends in US Retailing, in Krafft, M. Retailing in the 21st Century: Current and Future Trends, Springer: Berlin, 59-77.

Wendlandt, M.; Schrader, U. (2007) Consumer reactance against loyalty programs. In:

Westbrook, R.A., \& Black, W.C., (1985). A motivation-based shopper typology.Journal of Retailing 61(1), 78-104.

Wilson, L., Alexander, A., \& Lumbers, M., (2004).Food access and dietary variety among older people. International Journal of Retail and Distribution Management 2(2), 109-122.

Winstanley, M., (1997). What dries customer's satisfaction in commercial banking Commercial? Leading Review, 12(3), 36-42.

Wong, A., \& Sohal, A.S. (2006).Understanding the quality of relationships in consumer services: A study in a retail environment.International Journal of Quality \& Reliability Management, 23(3), 244-264.

Wong, C. B. (2005). The Influence of Customer Satisfaction and Switching Cost on Customer Retention: A Survey of Retail Internet Banking Users in Hong Kong. University of South Australia, 2004.

Wong, N., Rindfleisch, J. E., Burroughs.,\& M. Steenkamp. (2003). Do reversed- worded items confound measures in cross-cultural research? The case of the material values scale. Journal of consumer research, 30(1), 72-91.

Wong, Y., \& Maher, T.E. (1998).Doing business with dragons of different breeds: some important differences between China and Japan.Management Research News, 21 (4/5), 45-54.

Wood, C. M., \& Scheer, L. K. (1996). Incorporating Perceived Risk into Models of Consumer Deal Assessment and Purchase Intent.Advances in Consumer Research, 23, 399-404.

Woodruff, R., Scott, C, Schumann, D., Gardinal, S., \& Bums, M. (1991). The standards issues in cs/d research: A historical perspective. Journal of Consumer Satisfaction and Dissatisfaction and Complaining Behavior, 4,103-109.

Woodruff, R.B. (1997). Customer value: The next source for competitive advantage. Journal 


\section{Macrothink \\ Journal of Entrepreneurship and Business Innovation \\ ISSN 2332-8851 2014, Vol. 1, No. 1}

of the Academy of Marketing Science. 25(2), 139-153.

Yuen, E. T., \& Chan, S. L. (2010). The effect of retail service quality and product quality on customer sense of fulfillment. Journal of Database Marketing and Customer Strategy Management, 17(3/4), 222-240.

Zeithaml, V. (1985).Quality Counts In Services, Too, Business Horizons, 28(May-June), 44-52.

Zeithaml, V. (1988). Consumer perceptions of price, quality, and value: a means-end model and synthesis of evidence. Journal of Marketing, 52(July), 2-22.

Zeithaml, V. A., \& Bitner, M. J. (2003).Services marketing: Integrating Customer Focus across the Firm, McGraw-Hill, New York.

Zikmund, W. G. (2008). Exploring Marketing Research. USA: US GRATIS Foundation 